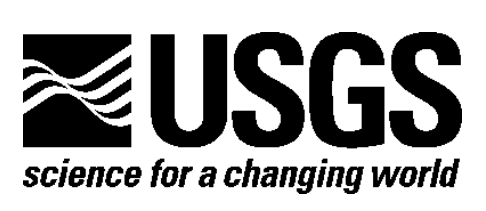

\title{
Sediment Geochemistry of Corte Madera Marsh, San Francisco Bay, California: Have Local Inputs Changed, 1830-2010?
}

Open-File Report 2013-1042

U.S. Department of the Interior U.S. Geological Survey 
This page left intentionally blank 


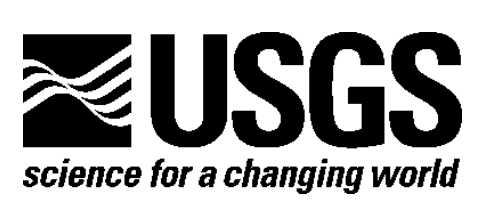

\section{Sediment Geochemistry of Corte Madera Marsh, San Francisco Bay, California: Have Local Inputs Changed, 1830-2010?}

By Renee K. Takesue and Bruce E. Jaffe

Open-File Report 2013-1042

U.S. Department of the Interior U.S. Geological Survey 


\section{U.S. Department of the Interior \\ SALLY JEWELL, Secretary}

U.S. Geological Survey

Suzanne M. Kimball, Acting Director

U.S. Geological Survey, Reston, Virginia: 2013

For more information on the USGS-the Federal source for science about the Earth, its natural and living resources, natural hazards, and the environment-visit

http://www.usgs.gov or call 1-888-ASK-USGS

For an overview of USGS information products, including maps, imagery, and publications, visit $h$ ttp://www.usgs.gov/pubprod

To order this and other USGS information products, visit $h$ ttp://store.usgs.gov

Suggested citation:

Takesue, R.K., and Jaffe, B.E., 2013, Sediment geochemistry of Corte Madera Marsh, San Francisco Bay, California: Have local inputs changed, 1830-2010?: U.S. Geological Survey Open-File Report 2013-1042, 23 p., http://pubs.usgs.gov/of/2013/1042/.

Any use of trade, product, or firm names is for descriptive purposes only and does not imply endorsement by the U.S. Government.

Although this report is in the public domain, permission must be secured from the individual copyright owners to reproduce any copyrighted material contained within this report. 


\section{Contents}

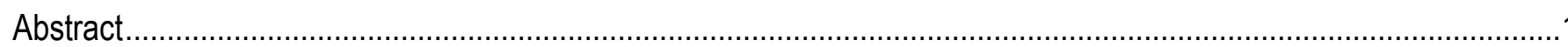

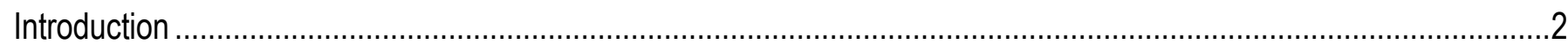

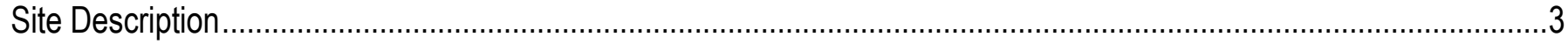

Approach

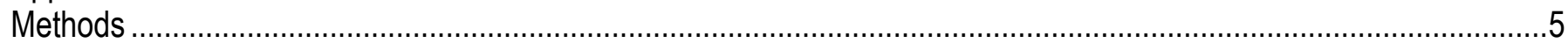

Marsh Sediment Collection ......................................................................................................................

Watershed and Bay Sediment Collection..................................................................................................

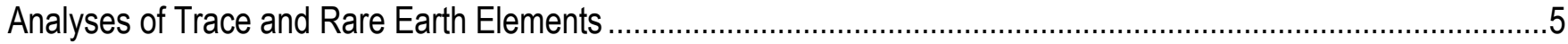

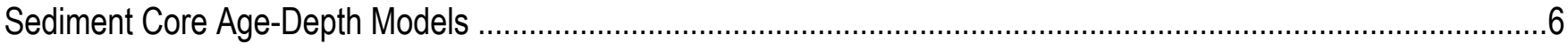

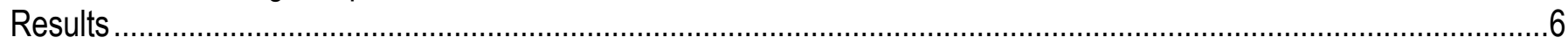

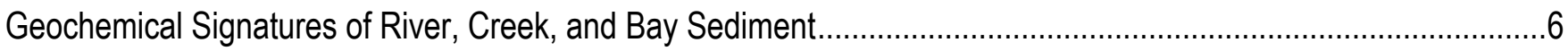

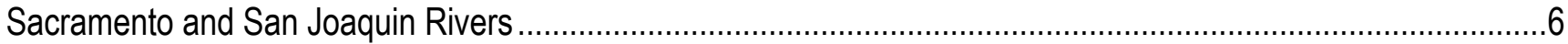

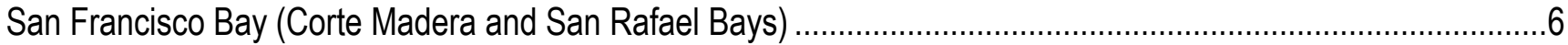

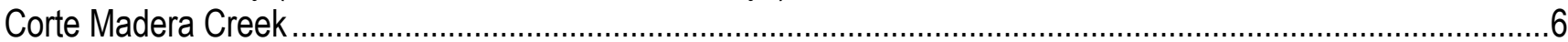

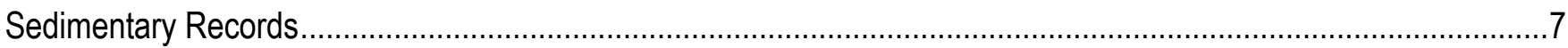

Historical Variations of Geochemical Tracers in Corte Madera Marsh .............................................................

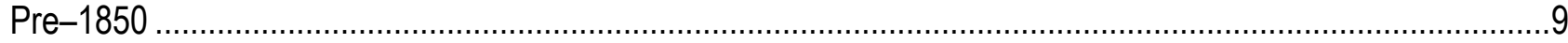

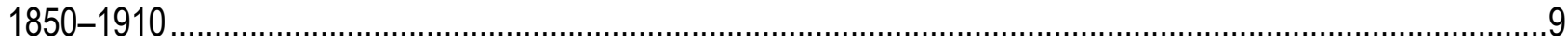

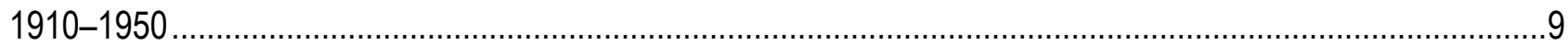

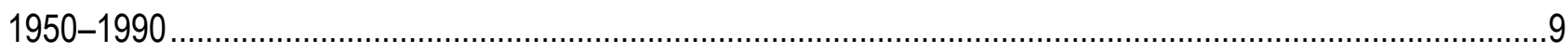

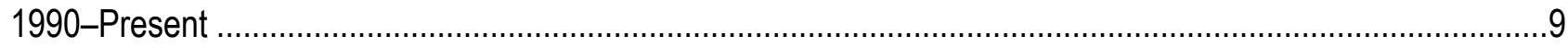

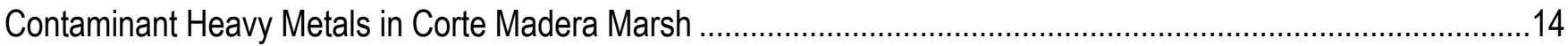

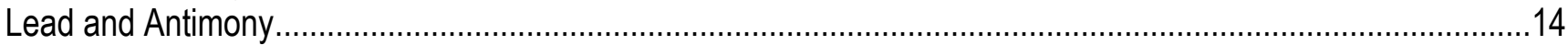

Iron, Cobalt, Copper, and Nickel .................................................................................................

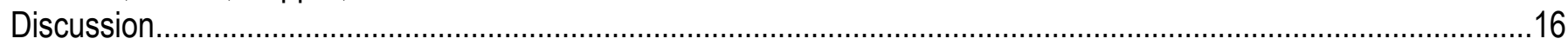

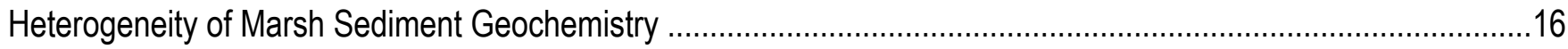

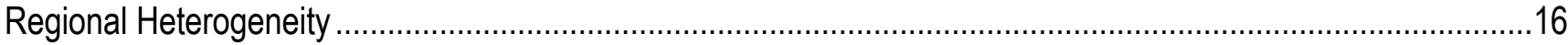

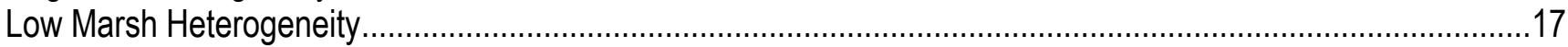

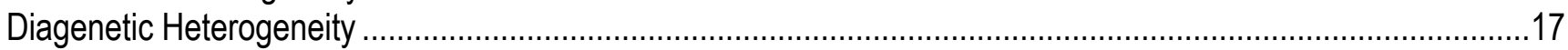

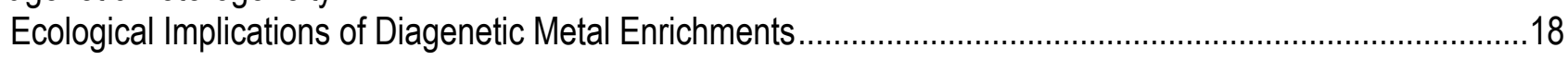

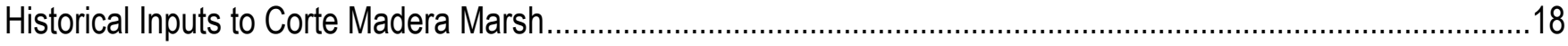

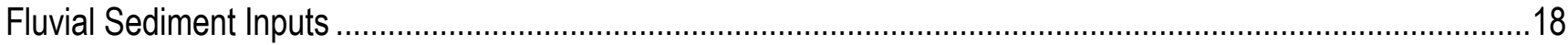

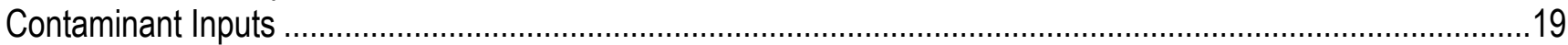

Current Sediment Budgets: Are Local Watersheds Making up the Difference? ....................................................19

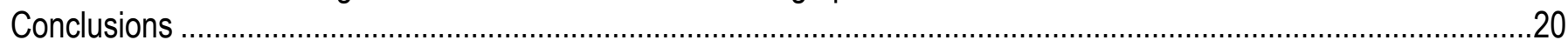

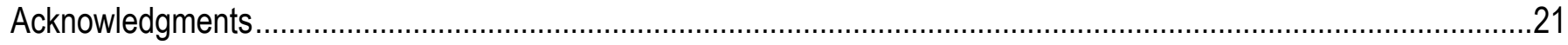

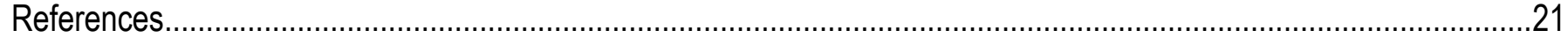




\section{Figures}

1. Map of the San Francisco Bay area and the Sacramento-San Joaquin Rivers and Delta. Circles show locations where river and creek sediment were collected; crosses show locations where bay mud was collected; diamond shows the location of the Selby lead smelter.

2. Aerial image of Corte Madera Marsh showing transects and core locations.

3. Graphs showing aluminum (Al)-normalized mean trace-element contents of fine sediment from Sacramento (SAC; $n=2$ ) and San Joaquin (SJ; n=2) Rivers, San Francisco Bay (Bay; n=8), and Corte Madera Creek (Creek; n=3). A) chromium (Cr), B) zirconium (Zr), C) scandium (Sc), D) thorium (Th), E) heavy rare earth elements (HREE), and $F$ ) total rare earth elements (TOT REE). Error bars show $\pm 1 \sigma ; n$, number of samples.

4. Graphs showing NASC-normalized mean rare earth element patterns in fine sediment from A) Rivers, B)

Bay and Creek, C) Corte Madera Marsh Transect $\mathrm{N}$ cores, and D) Corte Madera Marsh Transect $S$ cores.

The vertical scale of panel $A$ ) is two times larger than the others. Error bars show $\pm 1 \sigma$. 8

5. Graphs showing historical sediment-geochemical variations in Corte Madera Marsh cores from Transects $\mathrm{N}$ and S: aluminum (Al) content, Al-normalized thorium (Th) content, and Al-normalized total rare earth element (TOT REE) content.

6. Graphs showing historical sediment-geochemical variations in Corte Madera Marsh cores from Transects $\mathrm{N}$ and S: Al-normalized chromium $(\mathrm{Cr})$ content, Al-normalized zirconium $(\mathrm{Zr})$ content, and Al-normalized scandium (Sc) content.

7. Graphs showing NASC-normalized REE patterns in fine sediment from high, middle, and low marsh cores along Transect $\mathrm{N}$ for the five sediment-input periods.

8. Graphs showing NASC-normalized REE patterns in fine sediment from high, middle, and low marsh cores along Transect $S$ for the five sediment-input periods.

9. Graphs showing historical variations of $\mathrm{Al}$-normalized $\mathrm{Pb}$ and $\mathrm{Sb}$ contents of fine sediment from Corte Madera Marsh Transects N (top row of graphs) and S (bottom row of graphs)....

10. Graphs showing historical variations of Al-normalized Fe and Co contents of fine sediment from Corte Madera Marsh Transects N (top row of graphs) and S (bottom row of graphs).

11. Graph showing historical variations of Al-normalized Rb content of fine sediment in the three Corte Madera Marsh cores that spanned the period from pre-disturbance to present.

\section{Table}

1. Description of Corte Madera Marsh sedimentary records using a ${ }^{210} \mathrm{~Pb}-$ based CRS age model. 


\section{Conversion Factors}

Inch/Pound to SI

\begin{tabular}{|c|c|c|}
\hline Multiply & By & To obtain \\
\hline \multicolumn{3}{|c|}{ Length } \\
\hline inch (in.) & 2.54 & centimeter $(\mathrm{cm})$ \\
\hline inch (in.) & 25.4 & millimeter $(\mathrm{mm})$ \\
\hline inch (in.) & $2.54 \times 10^{4}$ & micrometer $(\mu \mathrm{m})$ \\
\hline foot $(\mathrm{ft})$ & 0.3048 & meter $(\mathrm{m})$ \\
\hline yard (yd) & 0.9144 & meter $(\mathrm{m})$ \\
\hline mile (mi) & 1.609 & kilometer $(\mathrm{km})$ \\
\hline \multicolumn{3}{|c|}{ Volume } \\
\hline gallon (gal) & 3.785 & liter $(\mathrm{L})$ \\
\hline \multicolumn{3}{|c|}{ Area } \\
\hline acre & 4,047 & square meter $\left(\mathrm{m}^{2}\right)$ \\
\hline acre & 0.4047 & hectare (ha) \\
\hline acre & 0.004047 & square kilometer $\left(\mathrm{km}^{2}\right)$ \\
\hline square inch $\left(\right.$ in $\left.^{2}\right)$ & 6.452 & square centimeter $\left(\mathrm{cm}^{2}\right)$ \\
\hline square foot $\left(\mathrm{ft}^{2}\right)$ & 929.0 & square centimeter $\left(\mathrm{cm}^{2}\right)$ \\
\hline square foot $\left(\mathrm{ft}^{2}\right)$ & 0.09290 & square meter $\left(\mathrm{m}^{2}\right)$ \\
\hline square mile $\left(\mathrm{mi}^{2}\right)$ & 259.0 & hectare (ha) \\
\hline square mile $\left(\mathrm{mi}^{2}\right)$ & 2.590 & square kilometer $\left(\mathrm{km}^{2}\right)$ \\
\hline \multicolumn{3}{|c|}{ Mass } \\
\hline ounce, avoirdupois (oz) & 28.35 & $\operatorname{gram}(\mathrm{g})$ \\
\hline ounce, avoirdupois (oz) & 0.02835 & milligram (mg) \\
\hline \multicolumn{3}{|c|}{ Liquid Concentration } \\
\hline pounds per gallon & $1.19826 \times 10^{5}$ & milligrams per liter (mg/L) \\
\hline \multicolumn{3}{|c|}{$\begin{array}{l}\left.\text { Temperature in degrees Celsius }\left({ }^{\circ} \mathrm{C}\right) \text { may be converted to degrees Fahrenheit ( }{ }^{\circ} \mathrm{F}\right) \text { as follows: } \\
{ }^{\circ} \mathrm{F}=\left(1.8 \times{ }^{\circ} \mathrm{C}\right)+32 \\
\text { Temperature in degrees Fahrenheit }\left({ }^{\circ} \mathrm{F}\right) \text { may be converted to degrees Celsius }\left({ }^{\circ} \mathrm{C}\right) \text { as follows: } \\
{ }^{\circ} \mathrm{C}=\left({ }^{\circ} \mathrm{F}-32\right) / 1.8 \\
\text { Vertical coordinate information is referenced to the insert datum name (and abbreviation) here for instance, “North American } \\
\text { Vertical Datum of } 1988 \text { (NAVD } 88) . " \\
\text { Horizontal coordinate information is referenced to the insert datum name (and abbreviation) here for instance, "North American } \\
\text { Datum of } 1983 \text { (NAD 83)." } \\
\text { Altitude, as used in this report, refers to distance above the vertical datum. }\end{array}$} \\
\hline
\end{tabular}


This page left intentionally blank 


\title{
Sediment Geochemistry of Corte Madera Marsh, San Francisco Bay, California: Have Local Inputs Changed, 1830-2010?
}

\author{
By Renee K. Takesue and Bruce E. Jaffe
}

\begin{abstract}
Large perturbations since the mid-1800s to the supply and source of sediment entering San Francisco Bay have disturbed natural processes for more than 150 years. Only recently have sediment inputs through the Sacramento-San Joaquin Delta (the Delta) decreased to what might be considered pre-disturbance levels. Declining sediment inputs to San Francisco Bay raise concern about continued tidal marsh accretion, particularly if sea level rise accelerates in the future. The aim of this study is to explore whether the relative amount of local-watershed sediment accumulating in a tidal marsh has changed as sediment supply from the Sacramento-San Joaquin Rivers has decreased. To address this question, sediment geochemical indicators, or signatures, in the fine fraction (silt and clay) of Sacramento River, San Joaquin River, San Francisco Bay, and Corte Madera Creek sediment were identified and applied in sediment recovered from Corte Madera Marsh, one of the few remaining natural marshes in San Francisco Bay. Total major, minor, trace, and rare earth element (REE) contents of fine sediment were determined by inductively coupled plasma mass and atomic emission spectroscopy. Fine sediment from potential source areas had the following geochemical signatures: Sacramento River sediment downstream of the confluence of the American River was characterized by enrichments in
\end{abstract}

chromium, zirconium, and heavy REE; San Joaquin River sediment at Vernalis and Lathrop was characterized by enrichments in thorium and total REE content; Corte Madera Creek sediment had elevated nickel contents; and the composition of San Francisco Bay mud proximal to Corte Madera Marsh was intermediate between these sources. Most sediment geochemical signatures were relatively invariant for more than 150 years, suggesting that the composition of fine sediment in Corte Madera Marsh is not very sensitive to changes in the magnitude, timing, or source of sediment entering San Francisco Bay through the Delta. Nor does there appear to be a ubiquitous increase in the proportion of fine sediment from Corte Madera watershed accumulating in the marsh during the last 20 years when sediment inflows through the Delta have decreased to predisturbance levels. We conclude that a large, well-mixed reservoir, such as the transportable fine sediment pool in San Francisco Bay, is the primary source of sediment to Corte Madera Marsh, and this source buffers the marsh against changes in sediment supply from the Delta and local watersheds. This study also found that Corte Madera Marsh sediment between about 10-30 centimeters depth is highly contaminated with lead, likely a legacy of lead smelter operations near Carquinez Strait and leaded gasoline use. 


\section{Introduction}

River-borne sediment delivery to San Francisco Bay, California, has changed substantially since urbanization began in the 1850 s. Historically, the majority of sediment was derived from the Sacramento and San Joaquin Rivers (Krone, 1979) (fig. 1). Between 1853 and 1884, hydraulic gold mining in the northwestern Sierra Nevada introduced nine times more sediment than typical into rivers and streams flowing into San Francisco Bay (Gilbert, 1917). Although intense unregulated hydraulic mining was relatively short-lived, its legacy persisted for decades (Krone, 1979, 1996; James, 1999, 2004), and regulated hydraulic mining resumed on a smaller scale in the 20th century (James, 2005). In the early to mid-1900s, a second pulse of sediment, about one-half as large as that from hydraulic mining, appeared to be associated with

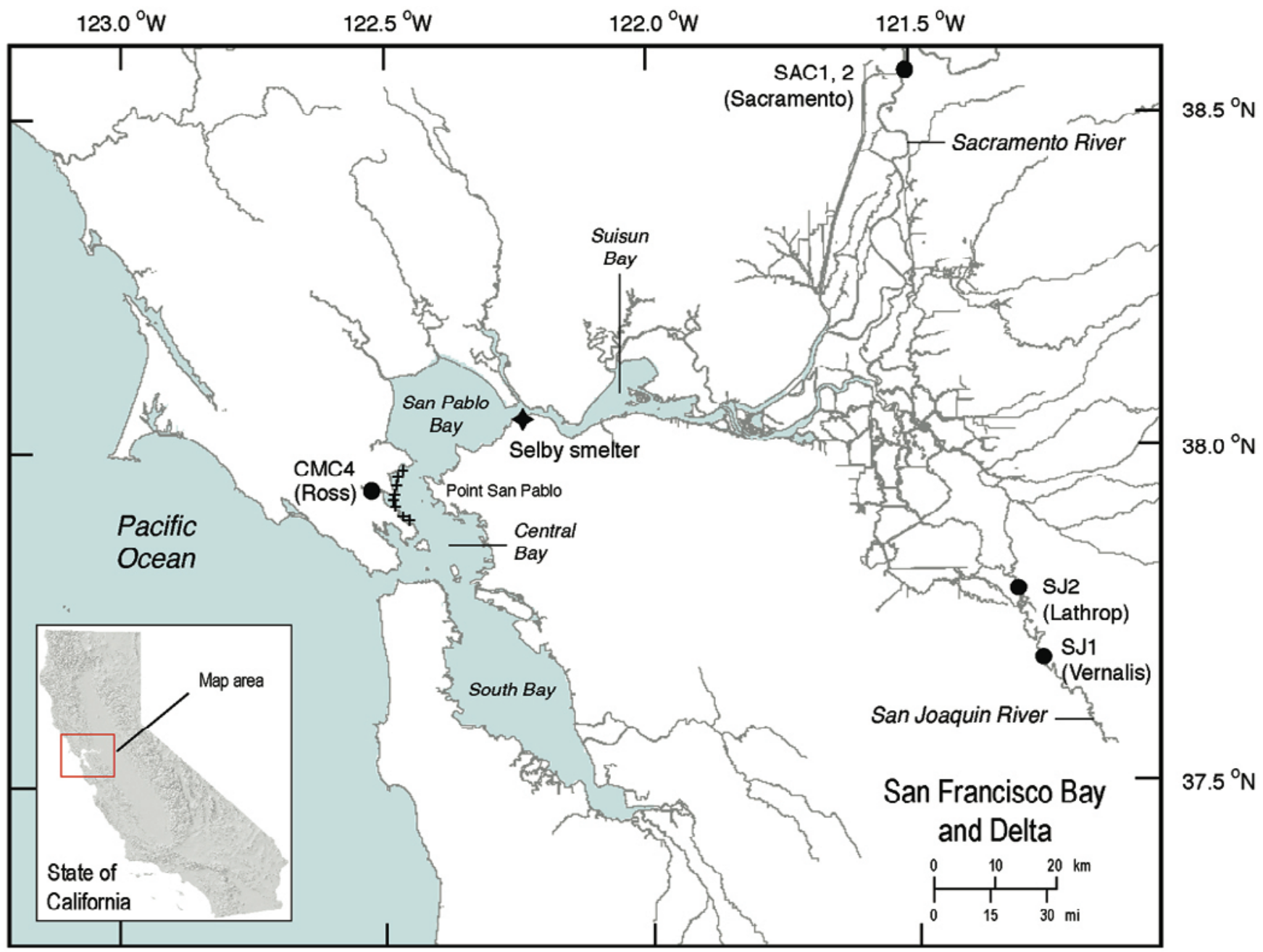

Basemap data from the Cal-Atlas Ocean and Hydrologic Features,

2008, at http://atlas.ca.gov. Shaded relief map (inset), U.S.

Geological Survey National Elevation Dataset, 2010,30 m

resolution.

Figure 1. Map of the San Francisco Bay area and the Sacramento-San Joaquin Rivers and Delta. Circles show locations where river and creek sediment were collected; crosses show locations where bay mud was collected; diamond shows the location of the Selby lead smelter. 
the urbanization of local watersheds and agricultural development of the Sacramento-San Joaquin Delta (the Delta) (Schoellhamer, 2011); however, there are insufficient measurements to corroborate this mechanism. After 1970, sediment input to San Francisco Bay decreased further because of the implementation of erosion controls in local watersheds (Wright and Schoellhamer, 2004) and the end of agricultural expansion (Schoellhamer, 2011). The magnitude of sediment input to San Francisco Bay through the Delta is estimated to be roughly similar today as that prior to human intervention (pre-1850) (Schoellhamer, 2011). Schoellhamer (2011) and references therein identify five periods (rounded to the nearest decade) of varying sediment input to San Francisco Bay: pre-1850, 1850-1910, 1910-1950, 1950-1990, 1990-present.

Tidal marshes in San Francisco Bay are nourished by siliciclastic sediment, typically silt and clay, that is carried by the tide and falls out of suspension when water flow slows over marsh vegetation (Reed, 2000). Tidal marshes began forming around San Francisco Bay about 6,000 years ago when the estuary took up its current position landward of the Golden Gate and sea level rise slowed to about 1-2 mm/yr (Atwater and others, 1979; Reed, 1995). Human perturbations have, until recently, resulted in excess sediment supply to San Francisco Bay that is thought to have created an erodible sediment pool on the bed (Schoellhamer, 2011), favoring tidal marsh creation or expansion (Atwater and others, 1979; Watson, 2008). Since the depletion of this erodible sediment pool in the late 1990s, the transport of suspended sediment by the tides in San Francisco Bay has become supply-limited (Schoellhamer, 2011). The present-day source of sediment could be an important factor if tidal marsh accretion is to keep pace with sea level rise (Reed, 1995; Kennish, 2001; Watson, 2004; McKee and others, 2006; Watson and Byrne, 2012). Because of decreasing sediment inputs through the Delta since the mid-1900s, local watersheds are believed to account for 50 percent or more of the sediment flux to San Francisco
Bay (Schoellhamer and others, 2005; McKee and others, 2006), whereas, historically, the proportion was about 15 percent (Porterfield, 1980). This study aims to explore historical and present-day sources of sediment to Corte Madera Marsh, one of the few undisturbed historical marshes in San Francisco Bay (Atwater and others, 1979).

\section{Site Description}

Corte Madera Marsh has undergone few human perturbations, making it a site where it may be possible to recover historical sedimentary records. The $4 \mathrm{~km}^{2}$ tidal marsh lies to the south of Corte Madera Creek (fig. 2). Development in the marsh is limited to two power transmission towers in the low marsh, a houseboat community along the creek, and $0.05 \mathrm{~km}^{2}$ of fill at the landward edge. Marshland north of Corte Madera Creek has been developed into the Larkspur Ferry Terminal.

The watershed of Corte Madera Creek is small, $73 \mathrm{~km}^{2}$, and 90 percent of its area is developed for urban and residential use. In the 1960s, the lower reach of Corte Madera Creek was channelized and hardened for flood and erosion control. Ninety-one percent of sediment carried by the creek comes from the uplands (Smeltzer and others, 2000). Suspended-sediment concentrations during the five wet seasons (November-May) for which data are available (1978-80, 2010-11) averaged $38 \pm 17 \mathrm{mg} / \mathrm{L}$ (U.S. Geological Survey, 2012), about equal to the mean suspended-sediment concentration in the bay water column at nearby Point San Pablo during 1999-2006 (Schoellhamer, 2011).

\section{Approach}

The underlying geologies of watersheds that can contribute sediment to San Francisco Bay are quite distinct (Alt and Hyndman, 2000). Corte Madera Creek drains Franciscan rocks of the Coast Range, which consists of metamorphosed oceanic chert, shale, basalt, and 


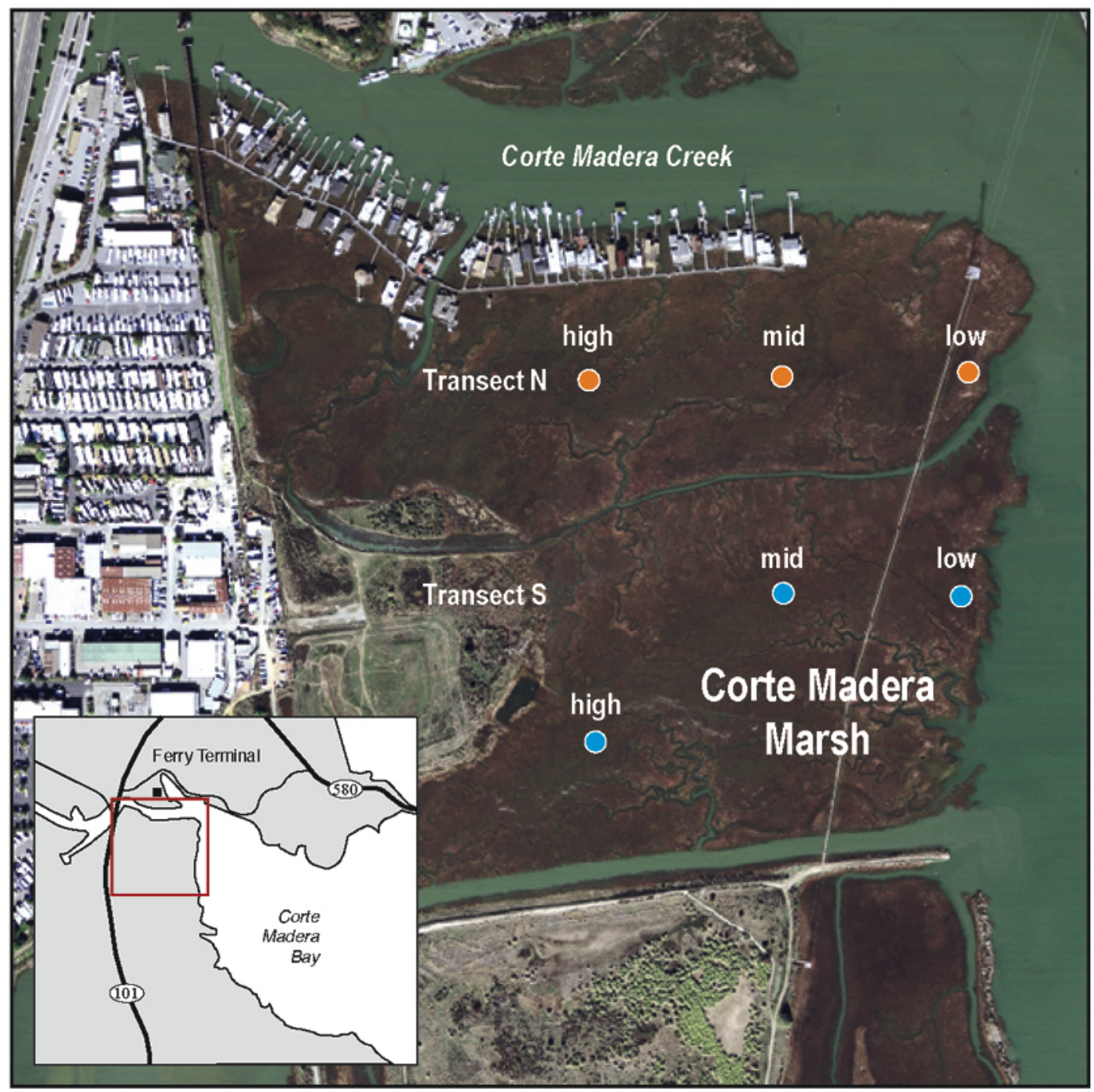

Background image from the U.S. Geological

Survey, downloaded on August 31, 2008

from Google Earth.

Figure 2. Aerial image of Corte Madera Marsh showing transects and core locations.

ultramafic rocks and serpentine (Murray and others, 1991). The Sacramento and San Joaquin Rivers and their tributaries drain the granitic Sierra Nevada Range (Alt and Hyndman, 2000) and its alluvium filling the Central Valley (Goldhaber and others, 2009). In addition, watersheds tributary to the Sacramento River, where most gold mining took place (the American, Bear, Yuba, and Feather watersheds), contain metamorphosed mafic and ultramafic oceanic crust interleaved with continental crust (Girty and others, 1996; Alt and Hyndman,
2000). These rocks have distinct mineralogical and geochemical compositions that can be preserved during weathering, erosion, and transport of sediment and used as source attributes once sediment has been deposited in distal locations (McLennan and others, 1993).

A geochemical approach was used to distinguish fine sediment ( $<63 \mu \mathrm{m}$, silt and clay) from Sacramento and San Joaquin Rivers, San Francisco Bay, and Corte Madera Creek-all potential sources of sediment to Corte Madera Marsh - and to describe how inputs from these 
sources varied historically in Corte Madera Marsh. Bay sediment is expected to be a mixture of river and local tributary sediment, and could include legacy sediment from the hydraulic mining period (Krone, 1996; Jaffe and others, 2007). Immobile trace elements, such as chromium $(\mathrm{Cr})$, scandium $(\mathrm{Sc})$, thorium $(\mathrm{Th})$, and zirconium $(\mathrm{Zr})$ and rare earth elements (REE), are the most reliable indicators of source-rock composition because of their refractory nature in minerals (Rollinson, 1993). Mafic and ultramafic rocks contain more $\mathrm{Cr}, \mathrm{Sc}$, and heavy $\mathrm{REE}$ (HREE; erbium [Er], thulium [Tm], ytterbium $[\mathrm{Yb}]$, and lutetium [Lu]) than granitic rocks or marine sediment, whereas granitic rocks contain more Th, Zr, light REE (LREE; lanthanum [La], cerium [Ce], praseodymium [Pr], neodymium $[\mathrm{Nd}]$, and promethium $[\mathrm{Pm}]$ ) and total REE (TOT REE) contents. Serpentine, which co-occurs with Franciscan and Sierran metamorphic rocks, is enriched in $\mathrm{Cr}$ and nickel (Ni) (Oze and others, 2004). The common rock-forming mineral hornblende and the accessory mineral sphene, which are associated with Sierran granite (Yancey and Lee, 1972), are enriched in the middle REE (MREE; samarium [Sm], europium [Eu], gadolinium [Gd], terbium [Tb], dysprosium [Dy], and holmium [Ho]).

\section{Methods}

\section{Marsh Sediment Collection}

Six $50 \mathrm{~cm}$-long sediment cores were collected in the low, middle, and high marsh in November 2010, January 2011, and May 2011 along Transects $\mathrm{N}$ and $\mathrm{S}$ (fig. 2) by colleagues from the University of San Francisco (USF). Cores were sectioned into $2 \mathrm{~cm}$-thick layers, dried at $60 \mathrm{C}$, and disaggregated. Subsamples of dried sediment were provided to the U.S. Geological Survey (USGS) for geochemical analyses.

\section{Watershed and Bay Sediment Collection}

Streambed sediment was collected from Corte Madera Creek at the town of Ross (Lagunitas Road bridge, $5.5 \mathrm{~km}$ upstream of the mouth) on June 30, 2011 (fig. 1). As part of a larger bay-wide sampling initiative, bay sediment was collected in Corte Madera and San Rafael Bays (fig. 1) using a Smith-McIntyre grab sampler aboard the USGS R/V Parke Snavely on January 27, 2012. Because of the ship's draft, bay sediment was collected between 1.5 and $2 \mathrm{~m}$ water depth. The upper 0-2 cm of sediment was subsampled on board ship and stored frozen until processing. River bank sediment was collected from the Sacramento River at Sacramento $(70 \mathrm{~km}$ upstream of the Delta) on October 18, 2010, and the San Joaquin River at Vernalis $(83 \mathrm{~km}$ upstream of the Delta) and Lathrup (66 km upstream of the Delta) on October 2, 2010 (fig. $1)$.

\section{Analyses of Trace and Rare Earth Elements}

Marsh, creek, river, and bay sediment was dried at $60 \mathrm{C}$, disaggregated, and dry-sieved in a stainless steel sieve to obtain $0.2 \mathrm{~g}$ of the fine fraction $(<63 \mu \mathrm{m}$ diameter). This aliquot was sent to the USGS Central Mineral and Environmental Resources Science Center, which sub-contracted SGS Laboratories, a nationally recognized testing laboratory, to measure total sedimentary contents of major, minor, trace, and REE elements. A sodium peroxide sinter and acid digestion were used to accomplish total sediment decomposition (Meier and Slowik, 2002), followed by inductively coupled plasma atomic emission and mass spectrometry quantification of total element concentrations. Major elements are reported on a weight percent basis (wt \%); trace elements are reported in parts per million (ppm), which is equivalent to micrograms per gram. Missing data represent samples without sufficient material to perform geochemical analyses.

Total sedimentary elemental contents were normalized by aluminum (Al) to account for differences in the amounts of silt, clay, and 
organic material in the fine fraction. Sedimentary REE contents were normalized by a North American shale composite (NASC) as given by Rollinson (1993) to show differences from average sedimentary rock. A sample with a shalelike REE composition would have $\mathrm{REE}_{\mathrm{NASC}}$ values $=1.0$.

\section{Sediment Core Age-Depth Models}

Sediment core age-depth models, or chronologies, based on activities of short-lived cosmogenic radionuclides ${ }^{137} \mathrm{Cs}$ and ${ }^{210} \mathrm{~Pb}$ were provided by J. Callaway (USF, unpub. data, 2012). Age-depth models based on the assumption of a constant rate of ${ }^{210} \mathrm{~Pb}$ supply (CRS) were adopted for the geochemical study because this approach accounts for variable sediment accumulation rates (Appleby and Oldfield, 1992). ${ }^{210} \mathrm{~Pb}$ radionuclide activities unsupported by the geologic background were undetectable or absent in sediment more than 100-150 years old. In the absence of other estimates of age-depth relationships, those determined by CRS in datable sediment horizons were linearly extrapolated to sediment horizons that could not be dated directly, a reasonable assumption for stable depositional environments (Appleby and Oldfield, 1992).

\section{Results}

\section{Geochemical Signatures of River, Creek, and Bay Sediment}

\section{Sacramento and San Joaquin Rivers}

Two samples of Sacramento River (SAC) sediment collected downstream of the confluence with the American River near downtown Sacramento had characteristics of both granitic and ultramafic source rocks: mean Al-normalized $\mathrm{Cr}, \mathrm{Zr}$, and HREE contents were highly enriched and Al-normalized Sc contents moderately enriched compared to sediment from other sources (fig. $3 A-C, E$ ). The HREE enrichment gave the mean $\mathrm{REE}_{\mathrm{NASC}}$ profile of SAC sediment a steep positive slope (fig. $4 A$ ) and a (Lu/La) NASC ratio $>1$ (fig. $3 E$ ). Average SAC sediment had a double-peaked MREE enrichment at $\mathrm{Eu}$ and $\mathrm{Tb}$ (fig. 4A).

San Joaquin River (SJ) sediment at Vernalis and Lathrop had a marked granitic character: high mean Al-normalized Th and TOT REE contents (fig. $3 D, F$ ) and a LREE enrichment (fig. $4 A$ ). The LREE enrichment gave the mean $\mathrm{REE}_{\mathrm{NASC}}$ profile of SJ sediment a negative slope (fig. $4 A$ ) and a (Lu/La) NASC $_{\text {ratio }}<1$ (fig. $3 E$ ). SJ sediment had a single-point MREE peak at Eu (fig. 4A).

\section{San Francisco Bay (Corte Madera and San Rafael Bays)}

Mean values of mafic rock indicators - Alnormalized $\mathrm{Cr}$, Sc, and a HREE enrichmentwere intermediate in San Francisco Bay sediment at 1-2 $\mathrm{m}$ depth in Corte Madera and San Rafael Bays compared to SAC and SJ sediment. San Francisco Bay sediment also had the lowest mean Al-normalized Zr content (fig. 3B). The mean REE $_{\text {NASC }}$ profile of bay sediment had characteristics of both mafic and granitic sources, having a slightly positive slope $(\mathrm{Lu} / \mathrm{La})_{\mathrm{NASC}}=1.1$ (fig. $3 E$ ) and a single-point MREE enrichment at $\mathrm{Eu}$ (fig. 4B).

\section{Corte Madera Creek}

Streambed sediment from Corte Madera Creek at Ross had the second-highest mean Alnormalized $\mathrm{Cr}$ content and lowest mean Alnormalized Sc content among the potential sources of sediment to Corte Madera Marsh (fig. $3 A, C$ ). The mean Al-normalized $\mathrm{Zr}$ content was lower than in river sediment but higher than in bay sediment (fig. $3 B$ ). The element $\mathrm{Ni}$ is enriched in mafic and ultramafic rocks and serpentine, such as are found in the Corte Madera watershed. The mean Al-normalized Ni value in Corte Madera Creek sediment was three times higher than in granitic SJ sediment and two times higher than in SAC and San Francisco Bay 

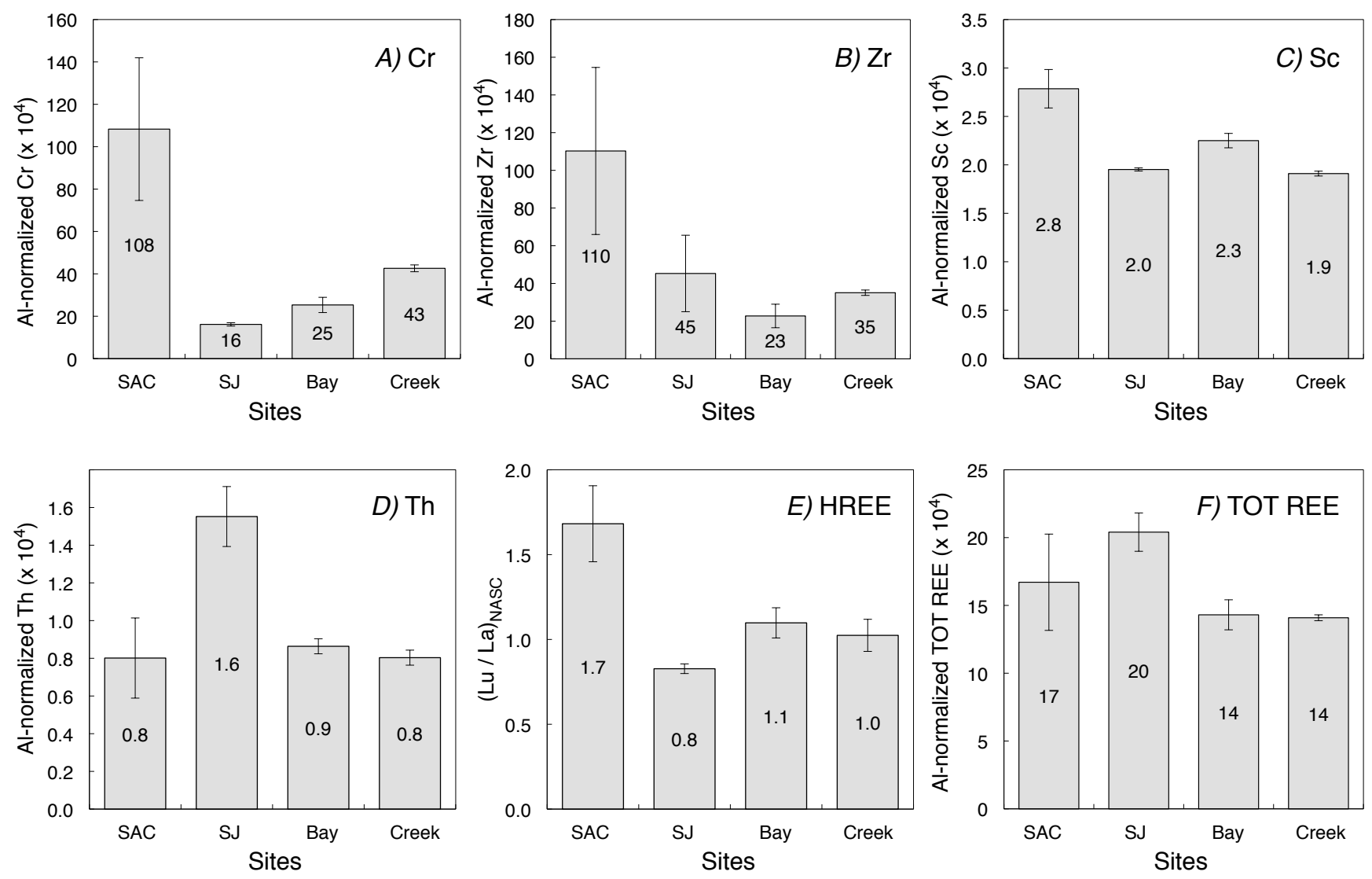

Figure 3. Graphs showing aluminum (Al)-normalized mean trace-element contents of fine sediment from Sacramento (SAC; $n=2$ ) and San Joaquin (SJ; n=2) Rivers, San Francisco Bay (Bay; $n=8)$, and Corte Madera Creek (Creek; $n=3)$. A) chromium $(\mathrm{Cr}), B$ ) zirconium $(\mathrm{Zr}), \mathrm{C}$ ) scandium (Sc), D) thorium (Th), E) heavy rare earth elements (HREE), and $F$ ) total rare earth elements (TOT REE). Error bars show $\pm 1 \sigma ; n$, number of samples.

sediment. The REE NASC $_{\text {profile of Creek }}$ sediment was relatively flat through the LREE (except La) and MREE (except Eu) and enriched in HREE (fig. 4B).

\section{Sedimentary Records}

${ }^{210} \mathrm{~Pb}$ - and ${ }^{137} \mathrm{Cs}$-based dating criteria were satisfactory in all but the low-marsh core from Transect S (J. Callaway, unpub. data, 2012). CRS chronologies suggest that three of the Corte Madera Marsh cores contain sediment records extending to the period before major perturbations to San Francisco Bay's sediment budget in the early 1850s (table 1). 

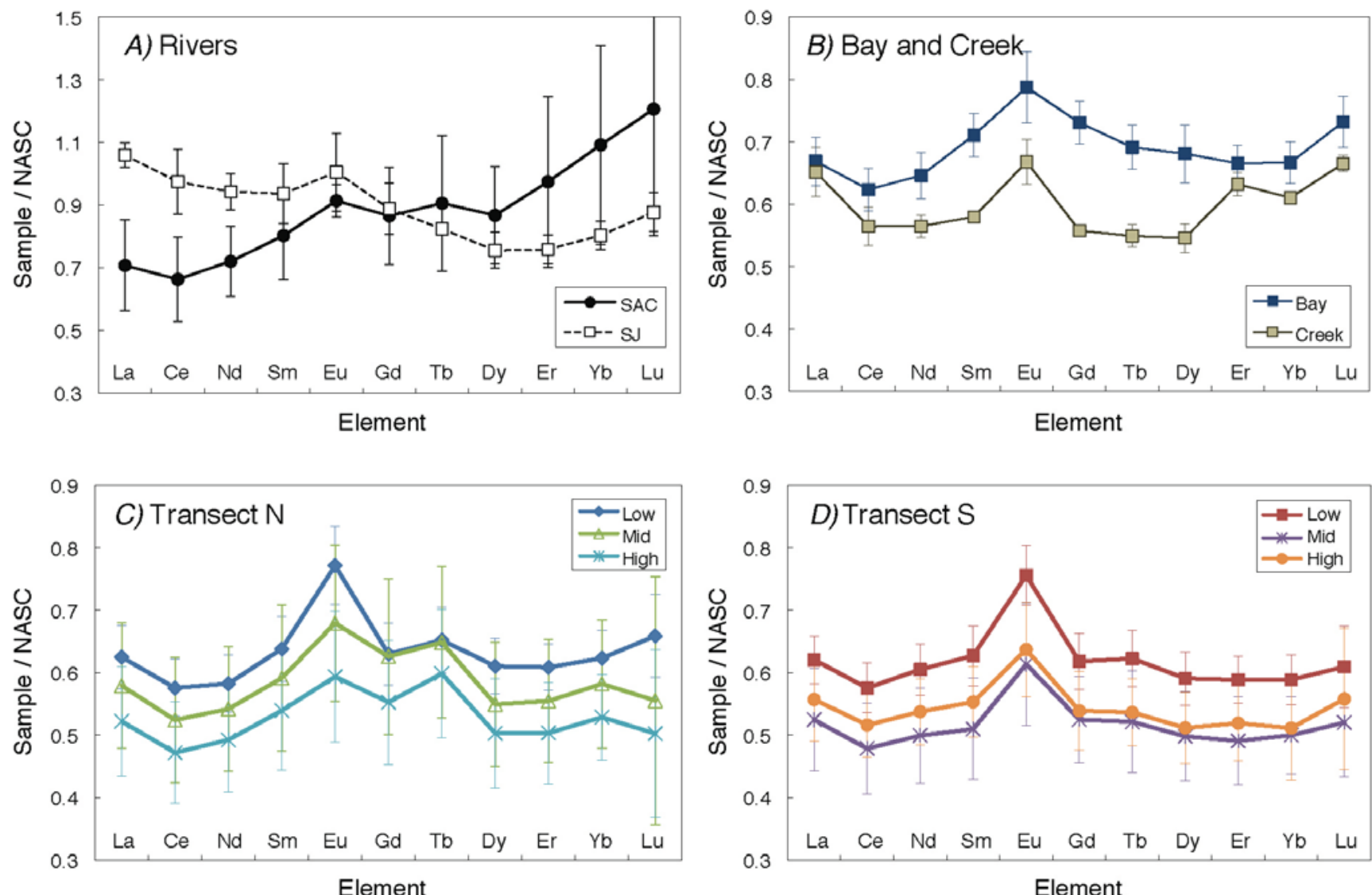

Figure 4. Graphs showing NASC-normalized mean rare earth element patterns in fine sediment from A) Rivers, B) Bay and Creek, C) Corte Madera Marsh Transect N cores, and D) Corte Madera Marsh Transect S cores. The vertical scale of panel $A)$ is two times larger than the others. Error bars show $\pm 1 \sigma$.

Table 1. Description of Corte Madera Marsh sedimentary records using a ${ }^{210} \mathrm{~Pb}-$ based CRS age model.

[Values in parentheses indicate a lower level of confidence in the age-depth relationship because there was not good agreement between the ${ }^{210} \mathrm{~Pb}$-based and ${ }^{137} \mathrm{Cs}$-based age models]

\begin{tabular}{lccc}
\hline \multicolumn{1}{c}{ Metric } & Low marsh & Middle marsh & High marsh \\
\hline \multicolumn{4}{c}{ Transect N } \\
\hline Record length (years) & 94 & 102 & \\
Start of record (date) & 1916 & 1908 & 1829 \\
\hline & Transect S & \\
\hline Record length (years) & $(124)$ & 176 & 163 \\
Start of record (date) & $(1887)$ & 1835 & 1848 \\
\hline
\end{tabular}




\section{Historical Variations of Geochemical Tracers in Corte Madera Marsh}

Sediment geochemical variations are described for the five sedimentation periods defined by Schoellhamer (2011).

Pre-1850

Corte Madera Marsh cores from the high marsh of Transect $\mathrm{N}$, the middle marsh of Transect S, and the high marsh of Transect S contained sediment deposited before 1850. All sediment deposited before 1850 had lower $\mathrm{Al}$ contents, 5-6 wt \% (fig. 5) than modern river, bay, and creek sediment, 7-8 wt \%. In the high marsh of Transect N, sediment deposited predisturbance had the lowest Al-normalized $\mathrm{Cr}$ content, being one third lower than in subsequently deposited sediment (fig. 6) and among the lowest TOT REE contents (fig. 5). $\mathrm{REE}_{\mathrm{NASC}}$ patterns of pre-disturbance sediment were relatively flat with the exception of small positive Eu anomalies, and had magnitudes ranging 40-60 percent lower than the NASC (figs. 7, 8).

1850-1910

In the mid-1850s, the Al-normalized $\mathrm{Cr}$ content abruptly doubled in high marsh sediment of Transect $\mathrm{N}$ and remained high until present day (fig. 6). Other source-rock indicators - Th, TOT REE, Zr, and Sc - varied little during this period (figs. 5, 6). Marsh sediment had higher Al contents near the end of the period than at the beginning, when hydraulic mining impacts were greatest, but the increase was not monotonic and the timing differed along Transects $\mathrm{N}$ and $\mathrm{S}$ (fig. 5). Additionally, at the end of this period, a 4-6 cm-thick sediment layer, with double-peaked MREE enrichments and elevated magnitudes, was deposited across the entire marsh in the late 1880 s or early 1900 s (figs. 7,8 ).
1910-1950

Sedimentary TOT REE contents increased slightly over this period (fig. 5), as did Alnormalized Cr (fig. 6). The 1900s was the first period when it was possible to compare sediment geochemistry among low, middle, and high marsh elevations. Sediment accumulating in the low marsh had higher and more variable Alnormalized $\mathrm{Zr}$ contents than sediment at higher elevations (fig. 6); however, marsh $\mathrm{Zr}$ contents were well below those of river, bay, and creek sediment (fig. 3). Along Transect N, low marsh sediment had lower and more variable Alnormalized Sc contents (fig. 6). These low marsh Sc contents were similar in magnitude to that of granitic SJ sediment and Corte Madera Creek sediment (fig. 3). Another distinctive characteristic of low marsh sediment was that it had higher, more shale-like REE NASC magnitudes, generally $0.6-0.8$, compared to middle or high marsh sediment, which had magnitudes generally ranging $0.4-0.7$ (figs. 7, 8). There also were differences in REE NASC $_{\text {patterns }}$ between Transects $\mathrm{N}$ and $\mathrm{S}$. Middle and high marsh sediment along Transect $\mathrm{N}$ generally had double-peaked MREE enrichments, whereas sediment along Transect $\mathrm{S}$ generally had a single MREE peak at Eu (figs. 7, 8).

1950-1990

Al-normalized $\mathrm{Cr}, \mathrm{Sc}$, and TOT REE contents increased slightly during this period (figs. 5, 6). For several years around 1980, sediment across all elevations of Transect $\mathrm{N}$ and possibly at the low marsh of Transect $\mathrm{S}$ had higher TOT REE contents (fig. 5) and doublepeaked MREE enrichments (figs. 7, 8) which, in combination, were characteristic of Sacramento River sediment.

1990-Present

The uppermost 6 or $8 \mathrm{~cm}$ of Corte Madera Marsh sediment were deposited during the last 20 years, when sediment inputs through the Delta were historically low. Al-normalized TOT REE contents decreased during this period in the low 
marsh of Transect $\mathrm{S}$, the middle marsh of Transect N, and the high marsh of Transect $\mathrm{S}$. Sediment deposited 4-6 cm below the surface (approximately 1994) in the middle marsh of Transect $\mathrm{S}$ had extremely high $\mathrm{Cr}$ and $\mathrm{Zr}$ contents and low Sc contents (fig. 6) accompanied by a HREE enrichment (fig. 8). Less extreme $\mathrm{Cr}$ and $\mathrm{Zr}$ enrichments also occurred in the surface layer $(0-2 \mathrm{~cm})$ at this site.

TRANSECT $\mathrm{N}$
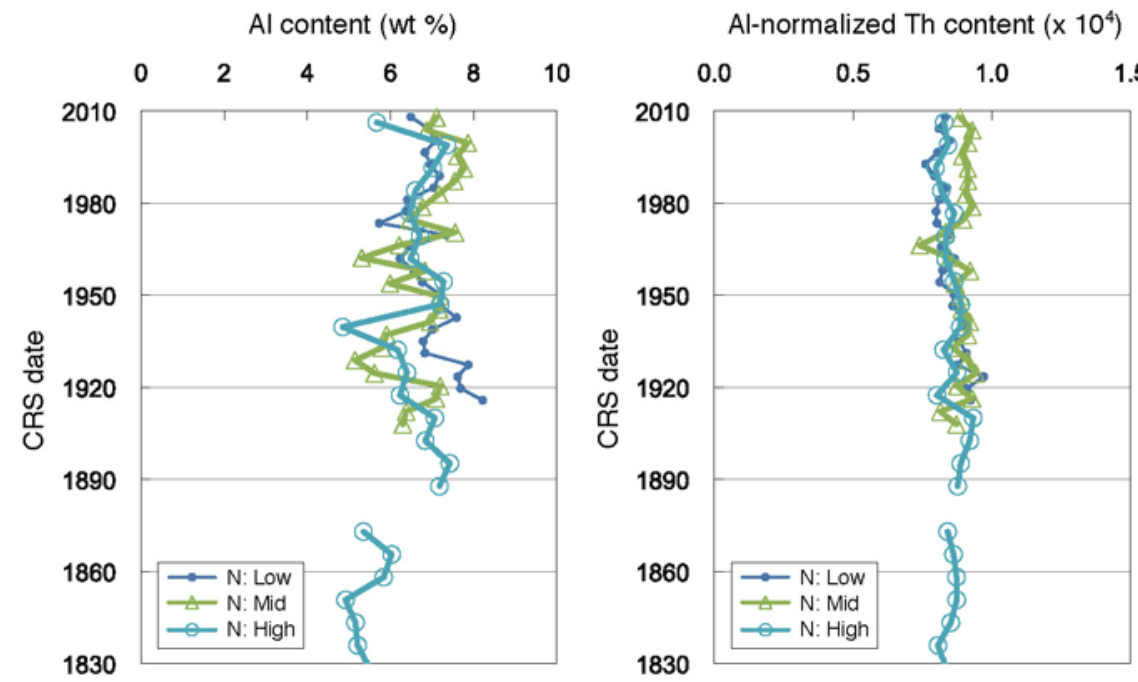

Al-normalized TOT REE content $\left(\times 10^{4}\right)$

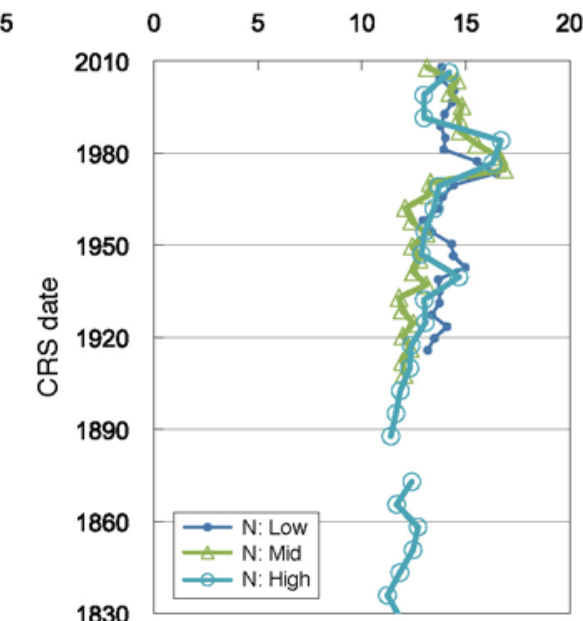

TRANSECT $S$
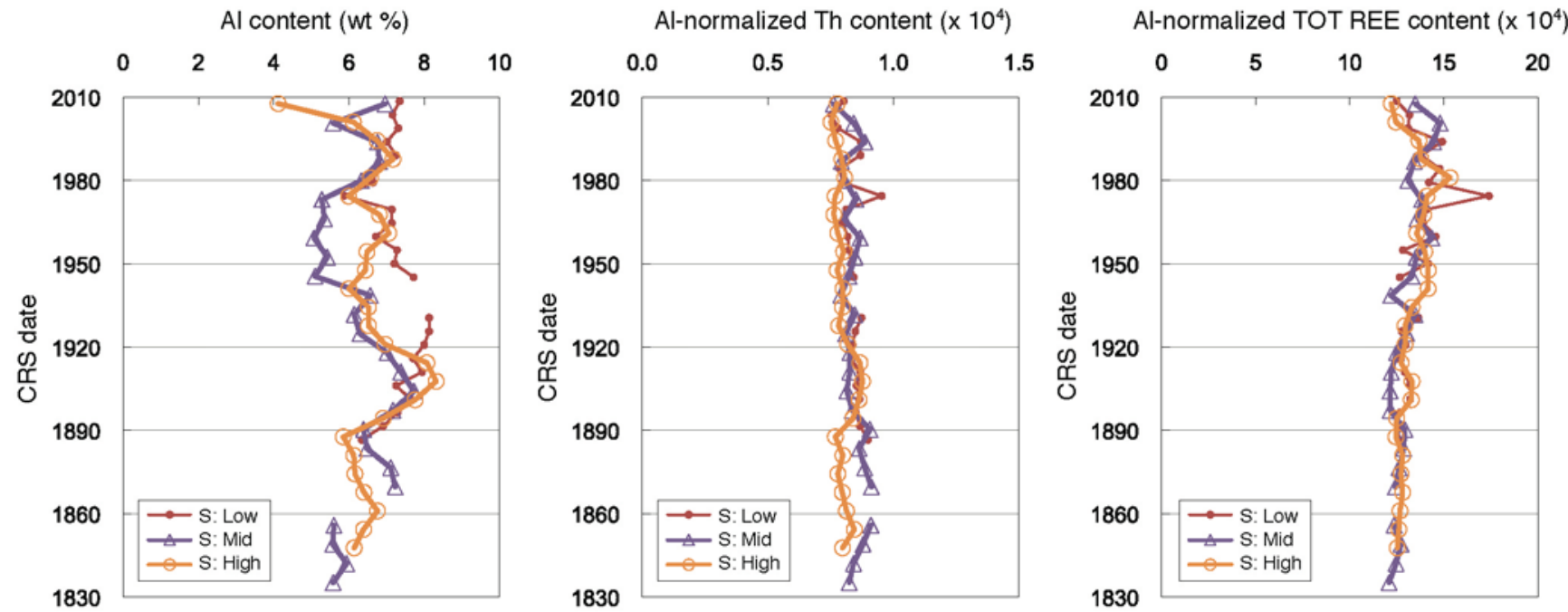

Figure 5. Graphs showing historical sediment-geochemical variations in Corte Madera Marsh cores from Transects $\mathrm{N}$ and S: aluminum (Al) content, Al-normalized thorium (Th) content, and Al-normalized total rare earth element (TOT REE) content. 


\section{TRANSECT N}
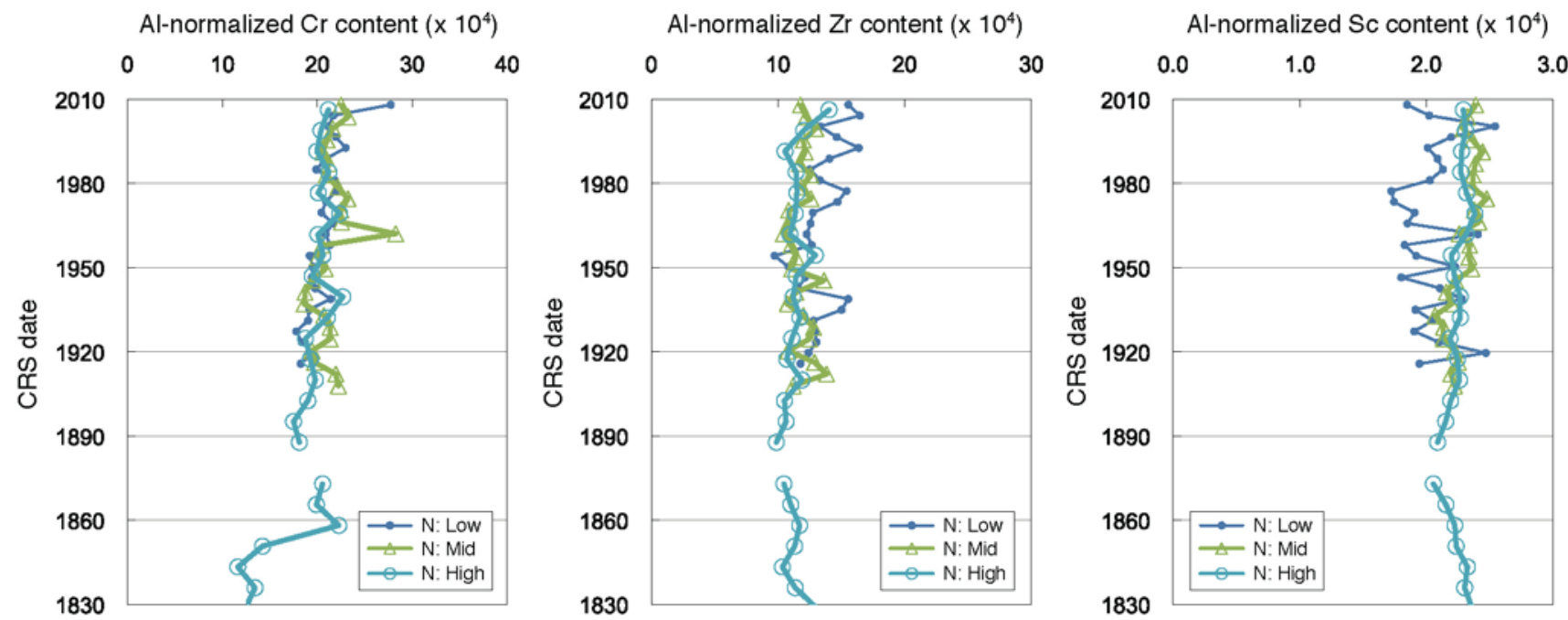

TRANSECT S
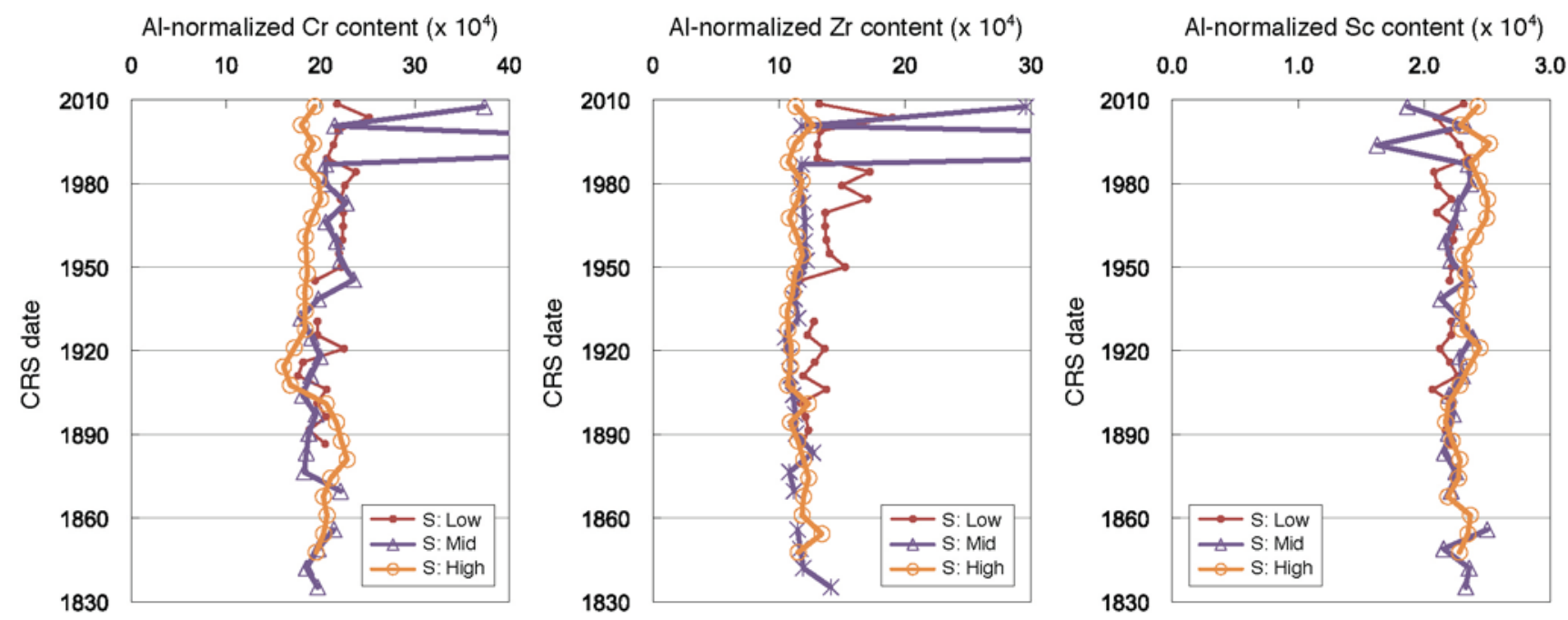

Figure 6. Graphs showing historical sediment-geochemical variations in Corte Madera Marsh cores from Transects $\mathrm{N}$ and S: Al-normalized chromium ( $\mathrm{Cr}$ ) content, Al-normalized zirconium ( $\mathrm{Zr}$ ) content, and Al-normalized scandium (Sc) content. 
Transect N, high marsh
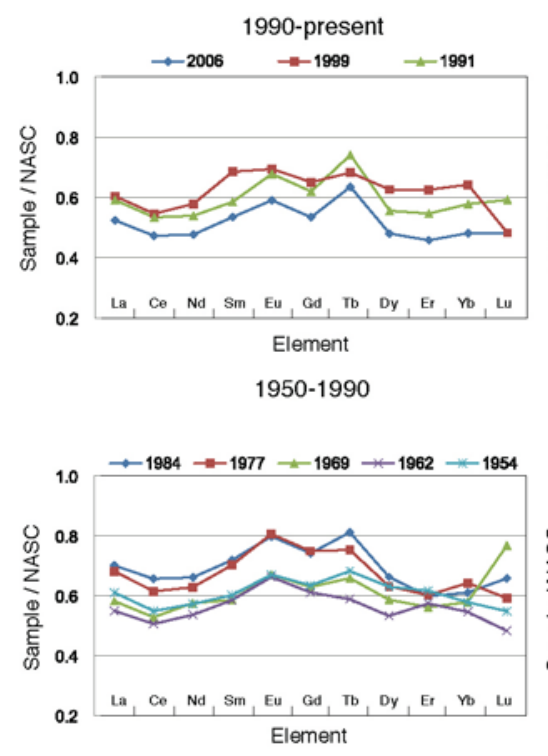

1910-1950
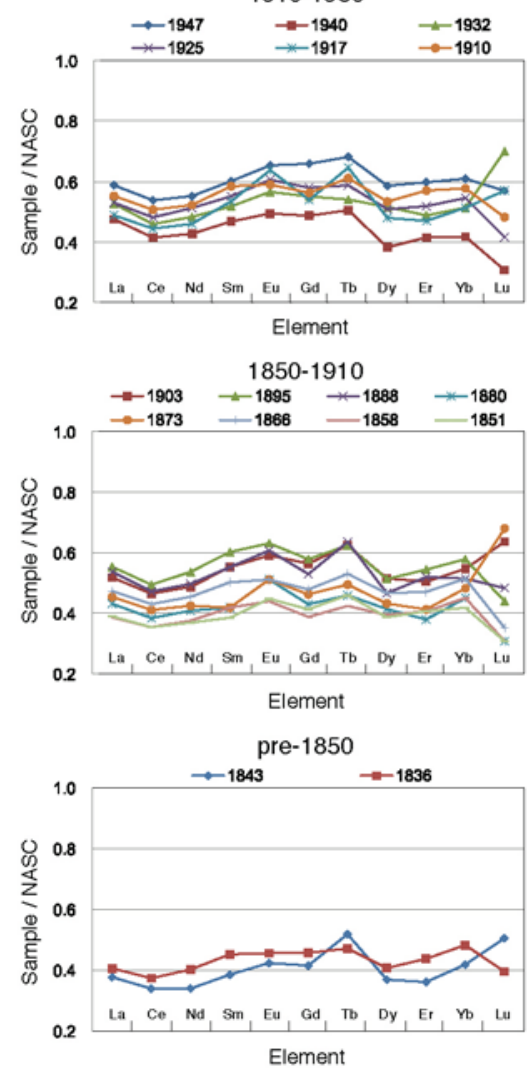

Transect N, middle marsh

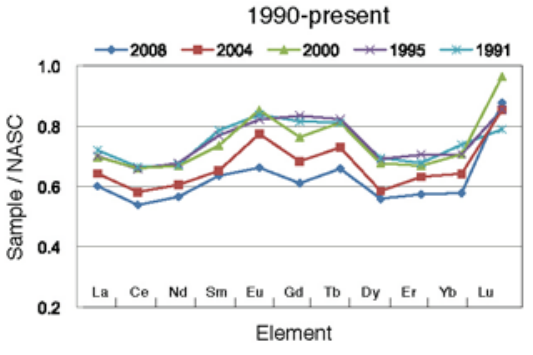

1950-1990

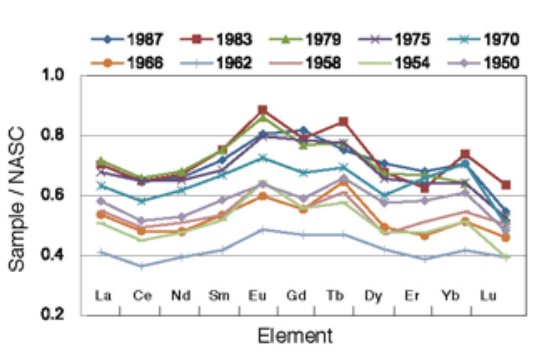

1910-1950
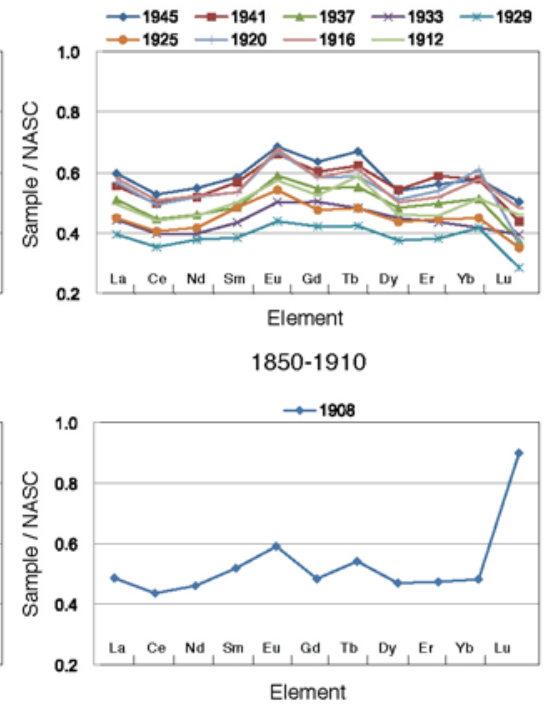

Transect N, low marsh

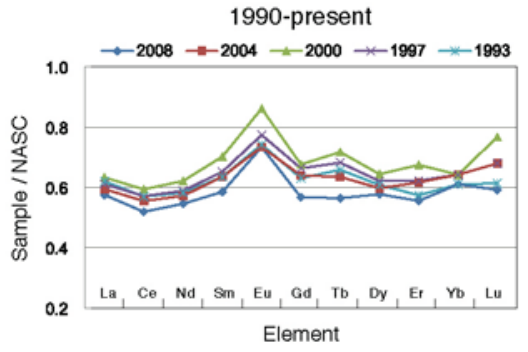

1950-1990

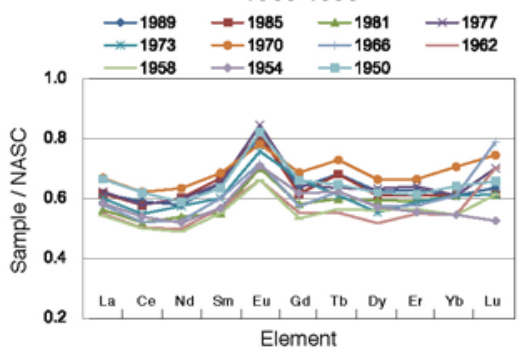

1910-1950

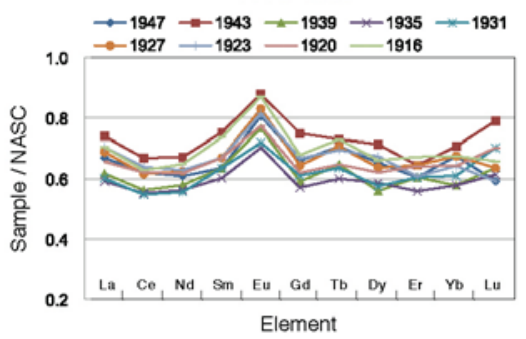

Figure 7. Graphs showing NASC-normalized REE patterns in fine sediment from high, middle, and low marsh cores along Transect $\mathrm{N}$ for the five sediment-input periods. 
Transect S, high marsh
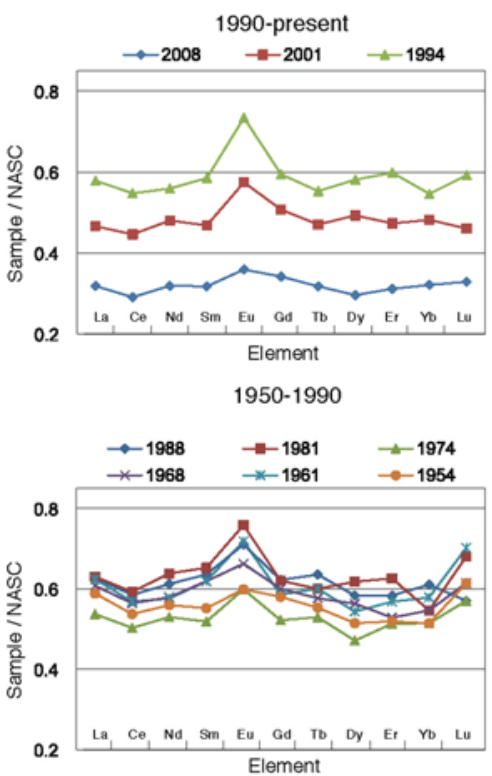

1910-1950
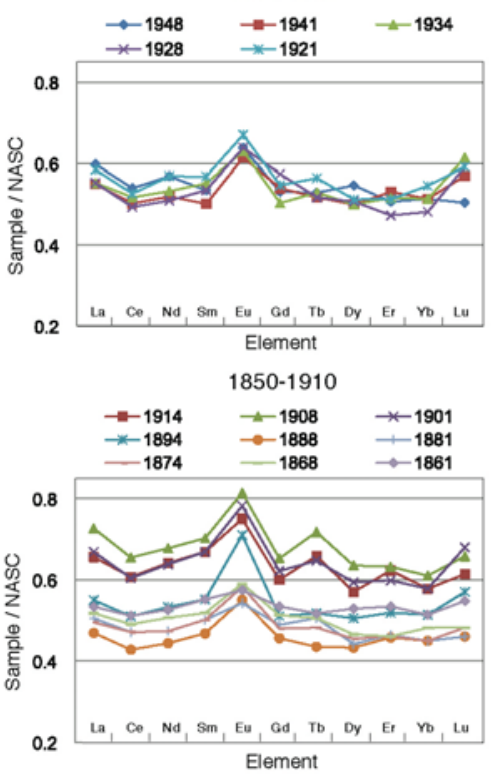

pre-1850

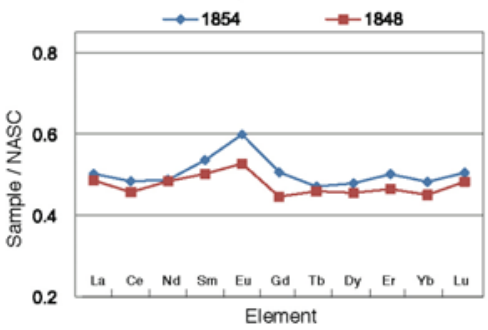

Transect S, middle marsh
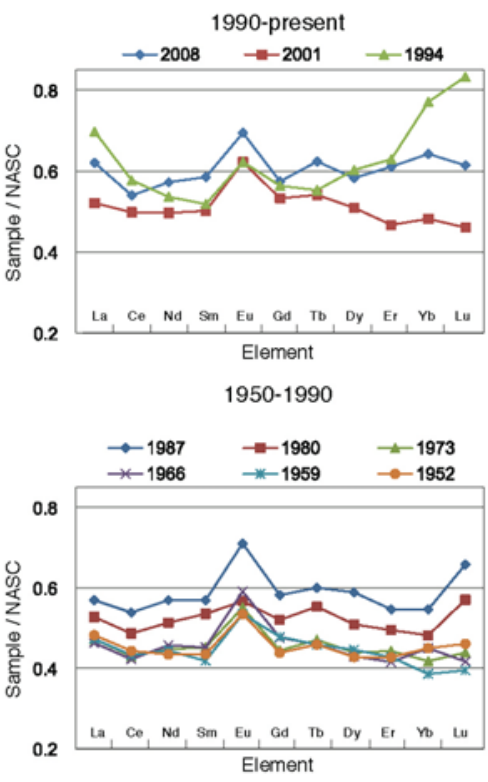

1910-1950

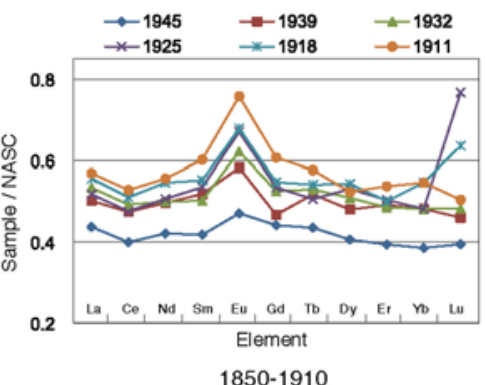

1850-1910

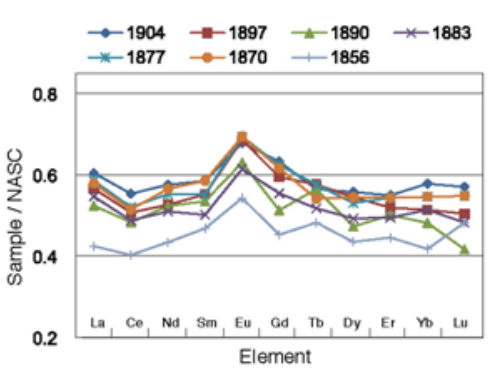

pre-1850

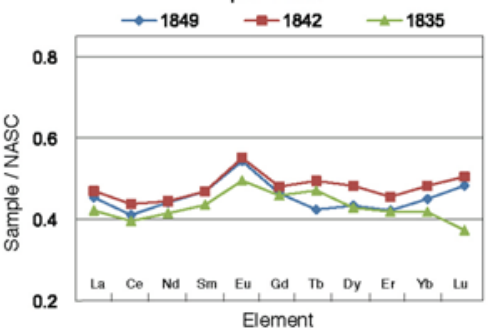

Transect S, low marsh
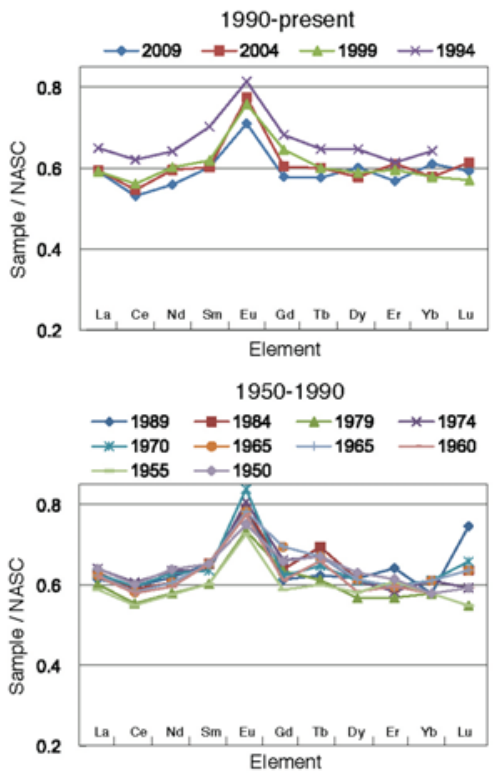

1910-1950
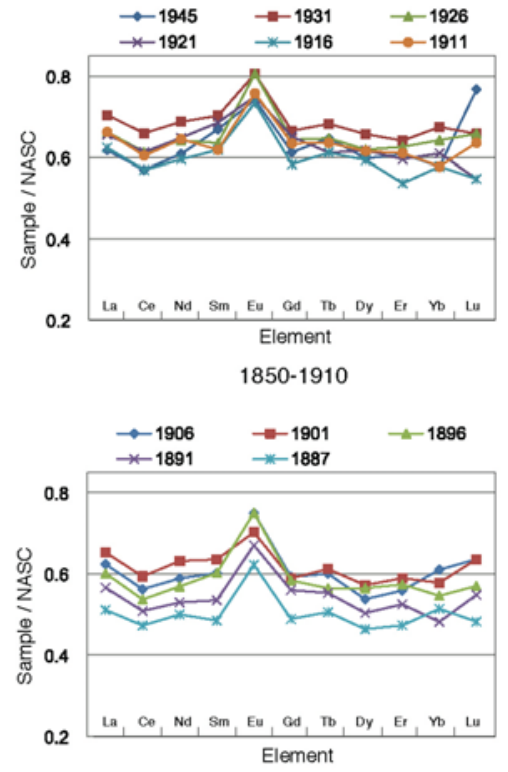
Element 


\section{Contaminant Heavy Metals in Corte Madera Marsh}

Several heavy metals associated with human industrial and urban activities were enriched in the sediment of Corte Madera Marsh. Downcore lead $(\mathrm{Pb})$ variations and potential sources were described in "Corte Madera Marsh Sediment Geochemistry, Part 1" (R. Takesue, written commun., 2011) without a temporal context. Here, ${ }^{210} \mathrm{~Pb}$-based CRS age models are used to give $\mathrm{Pb}$ and other trace metal variations a historical context.

\section{Lead and Antimony}

Natural background levels (pre-1850) of $\mathrm{Pb}$ and antimony $(\mathrm{Sb})$ in Corte Madera Marsh sediment were $15 \pm 2(1 \sigma)$ ppm and $0.7 \pm 0.1(1 \sigma)$ ppm, respectively. Concomitant $\mathrm{Pb}$ and $\mathrm{Sb}$ enrichments 2 times higher than background first appeared in the 1880s and became prevalent after 1900 (fig. 9). Highest $\mathrm{Pb}$ and $\mathrm{Sb}$ enrichments, around 30 and 15 times higher than background, respectively, occurred around 1950 in the middle and high marsh of Transect N. Sediment $\mathrm{Pb}$ and $\mathrm{Sb}$ contents were only about one-half as large along Transect $\mathrm{S}$, and were higher in the middle marsh than the high marsh. After $1980, \mathrm{~Pb}$ and $\mathrm{Sb}$ levels in Corte Madera Marsh sediment returned to moderately low levels, 2 and 3 times above pre-industrial background, respectively.

Iron, Cobalt, Copper, and Nickel

The transition metals iron (Fe), cobalt ( $\mathrm{Co})$, copper $(\mathrm{Cu})$, and nickel $(\mathrm{Ni})$ experienced concomitant subsurface enrichments to varying degrees depending on marsh elevation. Downcore profiles of $\mathrm{Fe}$ and $\mathrm{Cu}$ are shown in figure 10. In cores from Transect $\mathrm{N}$, highest enrichments occurred $36-42 \mathrm{~cm}$ below the marsh surface, and in cores from Transect $\mathrm{S}$ enrichments occurred from 36 to at least $52 \mathrm{~cm}$. Al-normalized Fe contents had the highest enrichments, 2 to 7 times above background levels, whereas $\mathrm{Co}, \mathrm{Ni}$, and $\mathrm{Cu}$ were between 1 and 4,2 , and 3 times above background, respectively. 

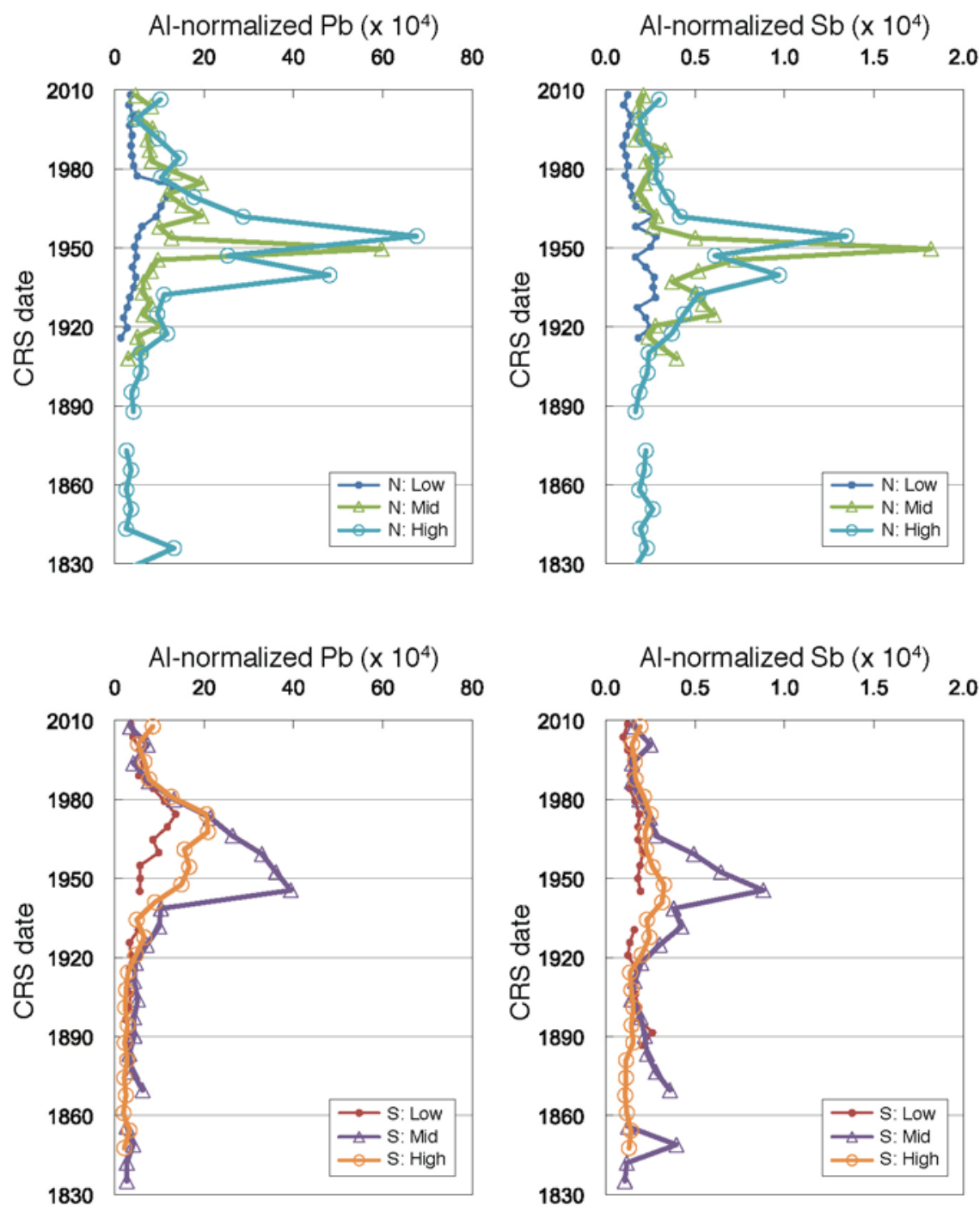

Figure 9. Graphs showing historical variations of Al-normalized $\mathrm{Pb}$ and $\mathrm{Sb}$ contents of fine sediment from Corte Madera Marsh Transects $\mathrm{N}$ (top row of graphs) and $\mathrm{S}$ (bottom row of graphs). 

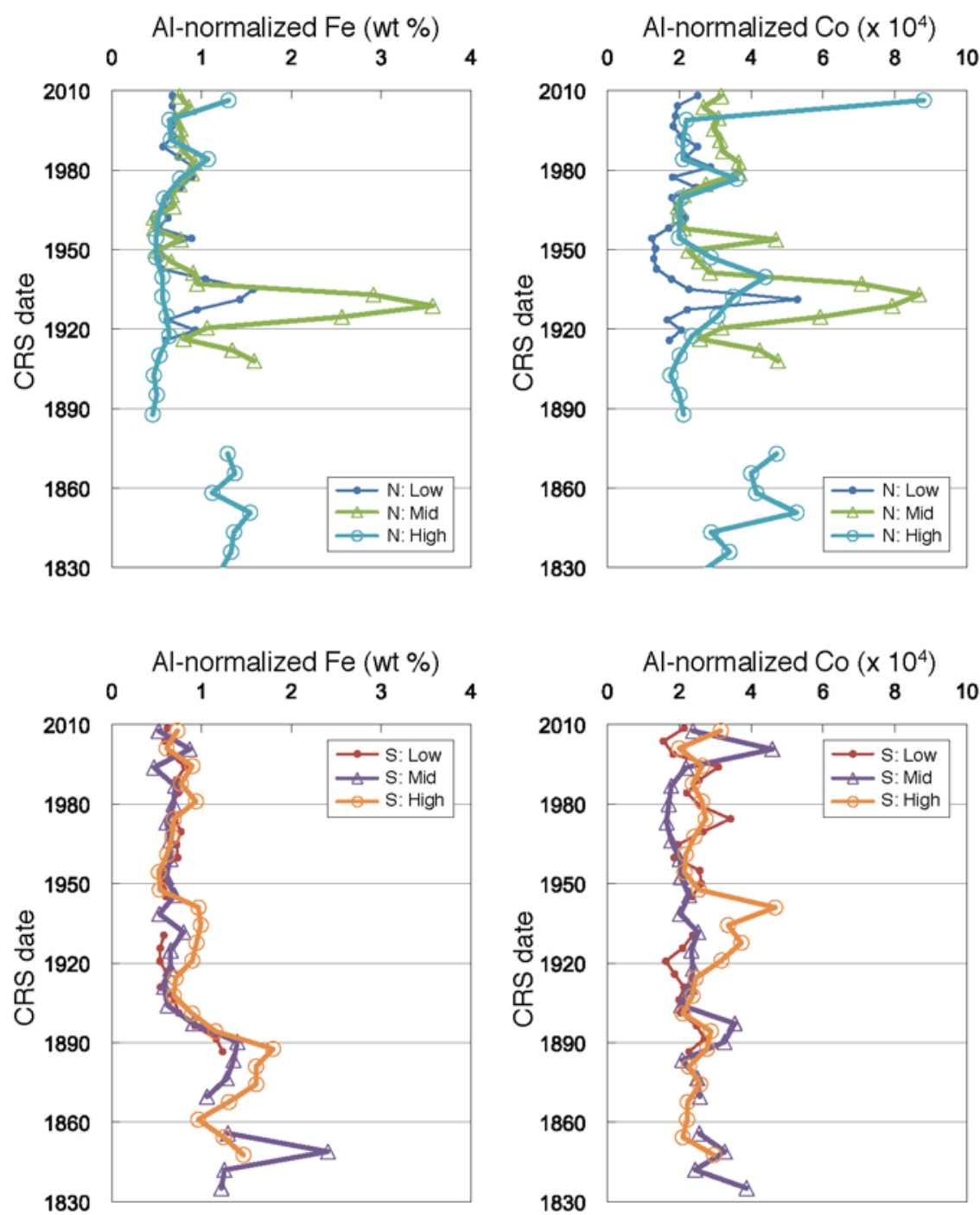

Figure 10. Graphs showing historical variations of Al-normalized Fe and Co contents of fine sediment from Corte Madera Marsh Transects N (top row of graphs) and S (bottom row of graphs).

\section{Discussion}

Variations of geochemical source-rock indicators in the sediment record of Corte Madera Marsh are consistent with our understanding of historical changes in sediment source and supply to San Francisco Bay. However, variations are ubiquitous across the whole marsh in only a few instances, raising a question about the significance of patterns. Before interpreting historical sediment geochemical variations in Corte Madera Marsh, it is important to understand the sources of variability in the sediment record.

\section{Heterogeneity of Marsh Sediment Geochemistry}

\section{Regional Heterogeneity}

Regional heterogeneity was evident from comparisons of sediment geochemistry along the north and south transects. Transect $\mathrm{N}$ is in an area of the marsh $150 \mathrm{~m}$ from Corte Madera Creek 
that contains tidal channels branching off from the creek. In contrast, Transect $\mathrm{S}$ is in an area of the marsh $450 \mathrm{~m}$ from the creek that does not contain creek-fed tidal channels. Thus the region of the marsh along Transect $\mathrm{N}$ is expected to receive a greater fraction of sediment from the local watershed than the region of the marsh along Transect $\mathrm{S}$. The REE $\mathrm{RASC}_{\mathrm{N}}$ patterns of sediment accumulating along Transects $\mathrm{N}$ and $\mathrm{S}$ were indeed different, particularly in the middle and high marsh. Sediment along Transect $\mathrm{N}$ was characterized by a double peak in the MREE (fig. 4C). Sediment along Transect $\mathrm{S}$, although containing a diminished double peak, was characterized by a single MREE peak at Eu that resembled the pattern in San Francisco Bay sediment (fig. 4D). Therefore some of the sediment geochemical heterogeneity between Transects $\mathrm{N}$ and $\mathrm{S}$ comes from greater inputs of San Francisco Bay sediment to the southern region of the marsh (Transect $\mathrm{S}$ ). This suggests that sedimentary records along Transect $\mathrm{N}$ are more suitable for studies about sediment input from Corte Madera watershed.

The lack of similarity of the REE $E_{\mathrm{NASC}}$ patterns, specifically the MREE double peak, in sediment from Corte Madera Creek at the town of Ross and sediment accumulating in the northern region of Corte Madera Marsh, suggests that the local watershed end member was not well defined in this study. Smeltzer and others (2000) determined that more than 90 percent of suspended sediment carried by Corte Madera Creek is eroded from the uplands. The assumption for the creek sampling scheme was that streambed fine sediment at the town of Ross was representative of fine sediment from upland basins and the material discharged by Corte Madera Creek. Because fine sediment at the landward edge of Corte Madera Marsh did not resemble fine sediment in the streambed at Ross, we concluded that fine sediment in the streambed at Ross was not a suitable corollary for fine sediment runoff from the local watershed.

\section{Low Marsh Heterogeneity}

Geochemical variations occurring only in low marsh cores point to a nearshore influence on the composition of sediment accumulating in the low marsh. The middle and high marsh are primarily affected by tidal flows (Reed, 2000; Lacy and Hoover, 2011), whereas the low marsh can be an energetic environment impacted by wind waves and ferry wakes (Lacy and Hoover, 2011). Waves and wakes resuspend sediment on intertidal mudflats (Brand and others, 2010; Lacy and Hoover, 2011) and this sediment can be deposited in the low marsh (Ganju and others, 2005). The influence of strong hydrodynamic forces acting on the low marsh is illustrated by elevated $\mathrm{Zr}$ contents and sporadic $\mathrm{Cr}, \mathrm{Zr}$, and HREE enrichments in low marsh cores. These elements are enriched in dense "heavy minerals" - chromite (Morrison and others, 2009), zircon (Hoskin and Ireland, 2000), and garnet (Grauch, 1989) - that require higher energies for mobilization and transport. Another line of evidence for a nearshore influence on low marsh sediment geochemistry is the higher magnitude of $\mathrm{REE}_{\mathrm{NASC}}$ patterns in the low marsh compared to the middle and high marsh. Low

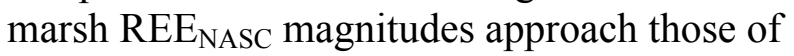
San Francisco Bay sediment, suggesting the presence of nearshore sediment in low marsh cores. Therefore, some of the sediment geochemical heterogeneity across marsh elevations is attributable to inputs of nearshore sediment by waves and wakes in the low marsh, making low marsh sedimentary records less suitable than middle and high marsh records for studies about sediment derived from Corte Madera watershed.

\section{Diagenetic Heterogeneity}

The covariance of $\mathrm{Fe}$ with $\mathrm{Co}, \mathrm{Ni}$, and $\mathrm{Cu}$, and to a lesser extent manganese ( $\mathrm{Mn})$, in deep sediment horizons of Corte Madera Marsh suggests that a diagenetic process was responsible for the heterogeneity of these metals in the sediment column. Sedimentary Fe is very sensitive to microbial (diagenetic) reduction- 
oxidation (redox) processes. Microbes reduce Fe and sulfate, making the ingredients for pyrite available. When pyrite precipitates in nearshore sediment, transition metals $\mathrm{Co}, \mathrm{Cu}$, and $\mathrm{Ni}$ commonly co-precipitate resulting in positive correlations with Fe in certain sediment horizons (Lord and Church, 1983; Huerta-Diaz and Morse, 1992), similar to the measurements in Corte Madera Marsh. Because subsurface redox processes can be site-specific, they can result in heterogeneous distributions of diagenetically sensitive elements in reducing marsh sediment.

\section{Ecological Implications of Diagenetic Metal Enrichments}

Diagenetic enrichments of sedimentary $\mathrm{Cu}$ and $\mathrm{Ni}$ are of concern because they can have adverse effects on biota (MacDonald, 1994). $\mathrm{Cu}$ contents of Corte Madera Marsh sediments $[\mathrm{mean}=47 \pm 10(1 \sigma) \mathrm{ppm}$, range $=31-98 \mathrm{ppm}]$ were less than the level at which adverse biological effects usually occur (108 ppm) (Florida Department of Environmental Protection, 1994). The Ni content of Corte Madera Marsh sediment, on the other hand [mean $=93 \pm 11(1 \sigma)$ ppm, range $=64-129 \mathrm{ppm}]$, always exceeded this level (43 ppm) (Florida Department of Environmental Protection, 1994) because of a high natural geologic background (Hornberger and others, 1999; Yee and others, 2007; Morrison and others, 2009).

\section{Historical Inputs to Corte Madera Marsh}

\section{Fluvial Sediment Inputs}

The primary fluvial sources of sediment to Corte Madera Marsh - the Sacramento and San Joaquin Rivers and Corte Madera Creek - had distinct geochemical signatures imparted by the rocks of their respective watersheds. However, sediment geochemical signatures in Corte Madera Marsh have varied little over historical time scales despite large human-induced perturbations to the source and supply of sediment to San Francisco Bay. One exception was a marsh-wide shift in REE NASC $_{\text {patterns and }}$ magnitudes around the turn of the 20th century that correspond with two large California floods in 1906 and 1909. The lack of increases of SAC and SJ geochemical indicators commensurate with the timing and magnitude of decadal-scale perturbations suggests that the geochemical composition of Corte Madera Marsh sediment was not very sensitive to sediment-input changes originating at the Delta. One explanation for this decoupling could be that the decades-long residence time of sediment in the northern reach of San Francisco Bay (Krone, 1979) combined with the distance $(60 \mathrm{~km})$ between the Delta and Corte Madera Marsh contributed to an attenuation or dilution of river-borne sedimentary signals. Another possible explanation for the discrepancy between expected and measured geochemical variations in Corte Madera Marsh is that historical sedimentological changes affected a coarser size fraction (sand-sized and larger particles) than typically accumulates in tidal marshes.

The element rubidium $(\mathrm{Rb})$ was not investigated here as a source-rock indicator because it is removed from parent rocks by weathering processes, yet its pattern of variation in Corte Madera Marsh sediment appears compelling. $\mathrm{Rb}$ is hosted in micas (biotite, muscovite) and potassium-rich feldspars (Mason and Moore, 1982), minerals characteristic of Sierra granite. During weathering, $\mathrm{Rb}$ is removed from primary minerals, adsorbs to secondary clays, and can be transported with the clay fraction (Nesbitt and others, 1980). In Corte Madera Marsh sediment, Al-normalized Rb ratios have a dog-leg pattern of variation: ratios are highest pre-disturbance; decrease quasi-linearly over a 20 year-long period beginning around 1860 or 1890 ; then stabilize at values that are 1117 percent lower through the present day (fig. 11). The discrepancy in the date of the apparent shift in the high marsh of Transect $\mathrm{S}$ could be related to an error in the age-depth model in older sediment horizons. The dog-leg pattern suggests 


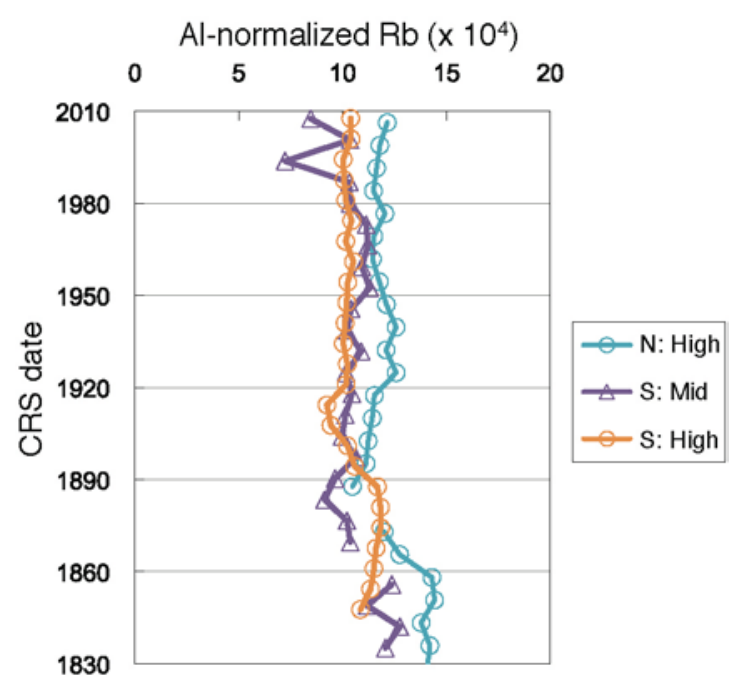

Figure 11. Graph showing historical variations of Al-normalized Rb content of fine sediment in the three Corte Madera Marsh cores that spanned the period from pre-disturbance to present.

there was a period of mixing of the pre-1860 inventory of transportable sediment in San Francisco Bay and a new, lower-Rb end member, and this period of mixing roughly coincided with the period when hydraulic mining inputs were greatest. The end result of the inferred input of lower-Rb sediment was a compositional shift of the transportable sediment inventory in San Francisco Bay that has persisted until present day.

\section{Contaminant Inputs}

Previous investigations of $\mathrm{Pb}$ and $\mathrm{Pb}$ isotopes in San Francisco Bay sediment cores identified an anthropogenic $\mathrm{Pb}$ increase (Hornberger and others, 1999; Ritson and others, 1999) but were unable to distinguish between smelter emissions and leaded gasoline aerosols as potential sources because of the similarity of their isotopic compositions (Rabinowitz and Wetherill, 1972; Ritson and others, 1999). The CRS age model forecasts initial modest increases in marsh $\mathrm{Pb}$ contents (to about $40 \mathrm{ppm}$ ) several decades prior to the introduction of leaded gasoline in 1923, which uniquely ascribes this initial $\mathrm{Pb}$ increase to smelter emissions. Highest $\mathrm{Pb}$ enrichments in marsh sediment, over 400 ppm, occurred during a period when both the smelter and leaded gasoline were in use. Two lines of evidence point to a smelter source for the highest degree of $\mathrm{Pb}$ contamination in the sediment record of Corte Madera Marsh. First, $\mathrm{Pb}$ enrichments were accompanied by $\mathrm{Sb}$ enrichments; $\mathrm{Sb}$ is a component of $\mathrm{Pb}$ ore and cooccurs with $\mathrm{Pb}$ in emissions and fallout from smelters (Ragaini and others, 1977). Second, the magnitude of the $\mathrm{Pb}$ enrichment in Corte Madera Marsh, more than $600 \mathrm{~m}$ from the highway, was higher than would be expected from a vehicular source. Around major highways, soil $\mathrm{Pb}$ levels decrease exponentially within a few hundred meters of the road, reaching levels of $10 \mathrm{~s} \mathrm{ppm}$ (Ratcliffe, 1982; Trombulak and Frissell, 2000). Leaded gasoline consumption peaked in the early 1970s (Dunlap and others, 2000) and this source likely accounted for moderate $\mathrm{Pb}$ enrichments in marsh sediment between 1960 and 1980 that were unaccompanied by $\mathrm{Sb}$ enrichments.

\section{Current Sediment Budgets: Are Local Watersheds Making up the Difference?}

According to calculations by Schoellhamer and others (2005), normal water years are currently characterized by about equal amounts of sediment entering San Francisco Bay from local watersheds as through the Delta, whereas 
during 1955-90 sediment entering through the Delta was over a third higher. These patterns raise the question of whether sediment from local watersheds is playing a greater role in marsh accretion than in the past. In Corte Madera Marsh, the upper 6 or $8 \mathrm{~cm}$ of the sediment column correspond to the period used by Schoellhamer and others (2005) to describe the current sediment input period for San Francisco Bay. There was little indication based on sediment geochemistry that the proportion of sediment from the local watershed of Corte Madera Creek has increased over the last 20 years. Geochemical source-rock indicators were generally no different in the upper 6 or $8 \mathrm{~cm}$ of marsh sediment than in underlying horizons. One exception was the element $\mathrm{Ni}$, which is enriched in mafic and ultramafic rocks, serpentine, and wastewater. In one of the six cores (middle marsh of Transect S), Al-normalized Ni contents increased almost 30 percent between about 1987 and 2010. While this pattern is consistent with the expectation of greater local sediment input, it does not co-occur along Transect $\mathrm{N}$, the region of the marsh likely to contain a local watershed geochemical signal, and is thus too localized to be conclusive at this time.

\section{Conclusions}

Decreasing sediment inflows through the Sacramento-San Joaquin River Delta to San Francisco Bay raise concerns about the supply of sediment for future tidal marsh accretion. A sediment geochemical approach was used in Corte Madera Marsh, a relatively undisturbed natural marsh, to explore the question- are local watersheds making up the difference?

Sedimentary records recovered from Corte Madera Marsh spanned the period from around 1830 to 2010 , according to sediment chronologies based on the assumption of a constant rate of radionuclide supply and the linear extrapolation of age-depth relationships to sediment horizons that could not be dated directly. Over the last 150 years there have been large perturbations to the amount and source of sediment entering San Francisco Bay through the Sacramento-San Joaquin River Delta, and the fine fraction (silt- and clay-sized particles) of this sediment is geochemically distinct from fine sediment from Corte Madera watershed and San Francisco Bay, being enriched in $\mathrm{Cr}, \mathrm{Zr}, \mathrm{Sc}$, and HREE (SAC); and Th and TOT REE (SJ). Historical variations of these geochemical indicators were surprisingly small in the fine fraction of Corte Madera Marsh sediment, suggesting that there was not a quantitative relationship between fine sediment entering San Francisco Bay through the Delta and fine sediment accumulating in Corte Madera Marsh. There was a degree of marsh sediment geochemical heterogeneity that appeared to be related to the location of sediment cores relative to the nearshore edge of the marsh and Corte Madera Creek. Because of marsh geomorphology, sediment records at middle and high elevations of the northern region of Corte Madera Marsh were most likely to receive sediment inputs from the local watershed. However, there was little indication based on sediment geochemical indicators that local watershed inputs to the marsh have changed. Rather, the fine sediment sources to Corte Madera Marsh during 1990-2010 appear to be the same as the historical sources. This finding points to a large volume of relatively

homogeneous fine sediment that has persisted for decades as the primary source of sediment to Corte Madera Marsh, and is supported by historical sedimentary Rb contents. Transportable fine sediment in San Francisco Bay could be this source. If this is the case, then Corte Madera and other marshes around San Francisco Bay could be buffered against changes in sediment supply through the Sacramento-San Joaquin Delta and local watersheds as long as there is a reservoir of transportable fine sediment in San Francisco Bay (Reed, 1995). Legacy inputs of the contaminant $\mathrm{Pb}$ to Corte Madera Marsh are present 10-30 cm below the marsh surface and can be attributed to smelter emissions in sediment horizons in which $\mathrm{Sb}$ enrichments co-vary with $\mathrm{Pb}$ enrichments, and 
to leaded gasoline aerosols when $\mathrm{Sb}$ contents are close to the natural geologic background.

\section{Acknowledgments}

The authors thank the San Francisco District of the U.S. Army Corps of Engineers for funding that made this work possible; the California Department of Fish and Wildlife for permission to access Corte Madera Ecological Reserve; the San Francisco Bay Conservation and Development Commission for program coordination; John Callaway at the University of San Francisco for access to sediment core material and chronologies; Amy Foxgrover of the U.S. Geological Survey for assistance with maps; Leticia Diaz of the U.S. Geological Survey for assistance with sample processing; and Christopher Conaway and Maureen DowningKunz for suggestions that improved this manuscript.

\section{References}

Alt, D., and Hyndman, D.W., 2000, Roadside geology of Northern and Central California: Missoula, Mountain Press Publishing Company, 369 p.

Appleby, P.G., and Oldfield, F., 1992, Application of lead-210 to sedimentation studies, in Ivanovich, M., and Harmon, R.S., eds., Uranium-series disequilibrium: applications to earth, marine, and environmental sciences: Oxford, Clarendon Press, p. 731-778.

Atwater, B.F., Conard, S.G., Dowden, J.N., Hedel, C.W., MacDonald, R.L., and Savage, W., 1979, History, landforms, and vegetation of the estuary's tidal marshes, in Conomos, J.T., ed., San Francisco Bay-The Urbanized Estuary: San Francisco, Pacific Division of the American Association for the Advancement of Science, p. 347-386.

Brand, A., Lacy, J.R., Hsu, K., Hoover, D.J., Gladding, S., and Stacey, M.T., 2010, Windenhanced resuspension in the shallow waters of South San Francisco Bay-Mechanisms and potential implications for cohesive sediment transport: Journal of Geophysical ResearchOceans, v. 115, p. C11024.

Dunlap, C.E., Bouse, R.M., and Flegal, A.R., 2000, Past leaded gasoline emissions as a nonpoint source tracer in riparian systems: a study of river inputs to San Francisco Bay: Environmental Science and Technology, v. 34, p. 1211-1215.

Florida Department of Environmental Protection, 1994, Approach to the assessment of sediment quality in Florida coastal waters: Florida Department of Environmental Protection, Tallahassee, Florida, 123 p.

Ganju, N.K., Schoellhamer, D.H., and Bergamaschi, B.A., 2005, Suspended sediment fluxes in a tidal wetland: Measurement, controlling factors, and error analysis: Estuaries, v. 28, p. 812-822.

Gilbert, G.K., 1917, Hydraulic-mining debris in the Sierra Nevada: U.S. Geological Survey Professional Paper 105, 154 p.

Girty, G.H., Ridge, D.L., Knaack, C., Johnson, D., and Al-Riyami, R.K., 1996, Provenance and depositional setting of Paleozoic chert and argillite, Sierra Nevada, California: Journal of Sedimentary Research, v. 66, p. 107-118.

Goldhaber, M.B., Morrison, J.M., Holloway, J.M., Wanty, R.B., Helsel, D.R., and Smith, D.B., 2009, A regional soil and sediment geochemical study in northern California: Applied Geochemistry, v. 24, p. 1482-1499.

Grauch, R.I., 1989, Rare earth elements in metamorphic rocks, in Lipin, B.R., and McKay, G.A., eds., Geochemistry and mineralogy of rare earth elements: Washington, D.C., The Mineralogical Society of America, p. 147-167.

Hornberger, M.I., Luoma, S.N., van Geen, A., Fuller, C., and Anima, R., 1999, Historical trends of metals in the sediments of San Francisco Bay, California: Marine Chemistry., v. 64, p. 39-55.

Hoskin, P.W.O., and Ireland, T.R., 2000, Rare earth element chemistry of zircon and its use as a provenance indicator: Geology, v. 28, p. 627-630.

Huerta-Diaz, M.A., and Morse, J.W., 1992, Pyritization of trace metals in anoxic marine sediments: Geochimica Cosmochimica Acta, v. 56, p. 2681-2702.

Jaffe, B.E., Smith, R.E., and Foxgrover, A.C., 2007, Anthropogenic influence on sedimentation and intertidal mudflat change in San Pablo Bay, California: 1856-1983: Estuarine, Coastal and Shelf Science, v. 73, p. 175-187.

James, L.A., 1999, Time and persistence of alluvium: river engineering, fluvial geomorphology, and mining sediment in California: Geomorphology, v. 31, p. 265-290. 
James, L.A., 2004, Tailings fans and valley-spur cutoffs created by hydraulic mining: Earth Surf. Proc. and Land., v. 29, p. 869-882.

James, L.A., 2005, Sediment from hydraulic mining detained by Englebright and small dams in the Yuba basin: Geomorphology, v. 71, p. 202-226.

Kennish, M.J., 2001, Coastal salt marsh systems in the U.S.: a review of anthropogenic impacts: Journal of Coastal Research, v. 17, p. 731-748.

Krone, R.B., 1979, Sedimentation in the San Francisco Bay system, in Conomos, T.J., ed., San Francisco Bay - the urbanized estuary: San Francisco, Pacific Division of the American Association for the Advancement of Science, $p$. 85-96.

Krone, R.B., 1996, Recent sedimentation in the San Francisco Bay system, in Hollibaugh, J.T., ed., San Francisco Bay the Ecosystem: San Francisco, Pacific Division of the American Association for the Advancement of Science, p. 63-68.

Lacy, J.R., and Hoover, D.J., 2011, Wave exposure of Corte Madera Marsh, Marin County, California-a field investigation: U.S. Geological Survey OpenFile Report 2011-1183, 28 p.

Lord, C.J., and Church, T.M., 1983, The geochemistry of salt marshes: sedimentary ion diffusion, sulfate reduction, and pyritization: Geochimica Cosmochimica Acta, v. 47, p. 13811391.

MacDonald, D.D., 1994, Approach to the assessment of sediment quality in Florida coastal waters, Volume 1: Development and evaluation of sediment quality assessment guidelines: MacDonald Environmental Sciences, Ltd., 126 p.

Mason, B., and Moore, C.B., 1982, Principles of geochemistry: New York, John Wiley and Sons, $344 \mathrm{p}$.

McKee, L.J., Ganju, N.K., and Schoellhamer, D.H., 2006, Estimates of suspended sediment entering San Francisco Bay from the Sacramento and San Joaquin Delta, San Francisco Bay, California: Journal of Hydrology, v. 323, p. 335-352.

McLennan, S.M., Hemming, S., McDaniel, D.K., and Hanson, G.N., 1993, Geochemical approaches to sedimentation, provenance, and tectonics, in Johnsson, M.J., and Basu, A., eds., Processes controlling the composition of clastic sediment: Boulder, Geological Society of America Special Paper 284, p. 21-40.

Meier, A.L., and Slowik, T., 2002, Rare earth elements by inductively-coupled plasma mass spectrometry: U.S. Geological Survey Open-File Report 02-223-K, $10 \mathrm{p}$.

Morrison, J.M., Goldhaber, M.B., Lee, L., Holloway, J.M., Wanty, R.B., Wolf, R.E., and Ranville, J.F., 2009, A regional-scale study of chromium and nickel in soils of northern California, USA: App. Geochem., v. 24, p. 1500-1511.

Murray, R.W., Buchholtz ten Brink, M.R., Gerlach, D.C., Russ, G.P., and Jones, D.L., 1991, Rare earth, major, and trace elements in chert from the Franciscan Complex and Monterey Group, California: assessing REE sources to fine-grained marine sediments: Geochimica Cosmochimica Acta, v. 55, p. 1875-1895.

Nesbitt, H.W., Markovics, G., and Price, R.C., 1980, Chemical processes affecting alkalis and alkaline earths during continental weathering: Geochimica Cosmochimica Acta, v. 44, p. 1659-1666.

Oze, C., Fendorf, S., Bird, D.K., and Coleman, R.G., 2004, Chromium geochemistry in serpentinized ultramafic rocks and serpentine soils from the Franciscan Complex of California: American Journal of Science, v. 304, p. 67-101.

Porterfield, G., 1980, Sediment transport of streams tributary to San Francisco, San Pablo, and Suisun Bays, California, 1909-66 U.S. Geological Survey Water Resources Investigations Report 80-64, 92 p.

Rabinowitz, M.B., and Wetherill, G.W., 1972, Identifying sources of lead contamination by stable isotopes techniques: Environmental Science and Technology, v. 6, p. 705-709.

Ragaini, R.C., Ralston, H.R., and Roberts, N., 1977, Environmental trace metal contamination in Kellogg, Idaho, near a lead smelting complex: Environmental Science and Technology, v. 11, p. 773-781.

Ratcliffe, J.M., 1982, Lead in man and the environment: Chichester, Ellis Horwood Limited, $240 \mathrm{p}$.

Reed, D.J., 1995, The response of coastal marshes to sea-level rise: survival or submergence?: Earth Surface Processes and Landform., v. 20, p. 39-48.

Reed, D.J., 2000, Coastal biogeomorphology: an integrated approach to understanding the evolution, morphology, and sustainability of temperate coastal marshes, in Hobbie, J.E., ed., Estuarine Science- a synthetic approach to research and practice: Washington D.C., Island Press, p. 347-361.

Ritson, P.I., Bouse, R.M., Flegal, A.R., and Luoma, S.N., 1999, Stable lead isotopic analyses of historic and contemporary lead contamination of San 
Francisco Bay estuary: Marine Chemistry, v. 64, p. 71-83.

Rollinson, H.R., 1993, Using geochemical dataevaluation, presentation, interpretation: Harlow, Pearson Education Limited, 352 p.

Schoellhamer, D.H., 2011, Sudden clearing of estuarine waters upon crossing the threshold from transport to supply regulation of sediment transport as an erodible sediment pool is depleted: San Francisco Bay, 1999: Estuaries and Coasts, v. 34, p. 885-899.

Schoellhamer, D.H., Lionberger, M.A., Jaffe, B.E., Ganju, N.K., Wright, S.A., and Shellenbarger, G.G., 2005, Bay sediment budget: sediment accounting 101, in SFEI, Pulse of the estuarymonitoring and managing water quality in the San Francisco Estuary: Oakland, San Francisco Estuary Institute, p. 58-63.

Smeltzer, M., Reilly, J., and Dawdy, D., 2000, Geomorphic assessment of the Corte Madera Creek watershed: Stetson Engineers, Inc., San Rafael, California, $91 \mathrm{p}$.

Trombulak, S.C., and Frissell, C.A., 2000, Review of ecological effects of roads on terrestrial and aquatic communities: Conservation Biololgy, v. 14, p. 1830.

U.S. Geological Survey, 2012, National Water Information System (NWIS), USGS water data for the Nation: U.S. Geological Survey database, accessed on January 10, 2013, at http://waterdata.usgs.gov/nwis/.

Watson, E.B., 2004, Changing elevation, accretion, and tidal marsh plant assemblages in a South San Francisco Bay tidal marsh: Estuaries, v. 27, p. 684698.

Watson, E.B., 2008, Marsh expansion at Calaveras Point Marsh, South San Francisco Bay, California: Estuarine and Coastal Shelf Science, v. 78, p. 593602.

Watson, E.B., and Byrne, R., 2012, Recent (19752004) vegetation changes in the San Francisco Estuary, California, tidal marshes: Journal of Coastal Research, v. 28, p. 51-68.

Wright, S.A., and Schoellhamer, D.H., 2004, Trends in the sediment yield of the Sacramento River, California, 1957-2001: San Francisco Estuary and Watershed Science, v. 2, Article 2.

Yancey, T.E., and Lee, J.W., 1972, Major heavy mineral assemblages and heavy mineral provinces of the Central California Coast region: Geological Society of America Bulletin, v. 83, p. 2099-2104.

Yee, D., Grieb, T., Mills, W., and Sedlak, M., 2007, Synthesis of long-term nickel monitoring in San Francisco Bay: Environmental Research, v. 105, p. 20-33. 